\title{
The Relationship Between Leadership Styles And Employee Commitment At A Parastatal Company In South Africa
}

Ajay K Garg, TUT Business School, Pretoria, South Africa

D. Ramjee, TUT Business School, Pretoria, South Africa

\begin{abstract}
The influence of leadership style on employee commitment for the organisation has not been adequately addressed in the Parastatal companies in South Africa. A need therefore exists for greater understanding of the relationship between the leadership style and work-related attitudes (such as employee commitment) in order to develop a leadership style that will encourage organisational commitment. This study examined the relationship between leadership style, and employee commitment. Managers and their subordinates participated in the study. 348 questionnaires were distributed, 58 to managers and 290 to their subordinates. Final data for analysis included responses from 197 participants (34 managers, and 163 subordinates). 163 respondents rated their manager's leadership behaviour on Bass and Avolio's (1997) multi-factor leadership questionnaire (MLQ) and Meyer and Allen's (1997) organisational commitment questionnaire $(O C Q)$. A series of statistical procedures were followed to analyse the data. Hypotheses were tested on two levels. First, correlations among managers and subordinates with regard to the $M L Q$, and then the $M L Q$ versus the OCQ. Results revealed a weak positive yet significant relationship between transformational leadership and affective commitment, normative commitment and continuance commitment. Transactional leadership had a weak but significant positive correlation with normative commitment, and Laissez-faire results indicated a weak negative yet significant correlation to affective commitment and normative commitment. Overall findings from this study suggest that leadership styles do play important roles in determining levels of affective commitment, continuance commitment and normative commitment. This study contributes to the bank of findings relating to the development of leadership and organisational commitment, not only in South Africa, but within the Parastatal organisations in particular.
\end{abstract}

Keywords: Leadership Style; South African Leadership; Multifactor Leadership; Employee Commitment; Organizational citizenship Behaviour

\section{INTRODUCTION}

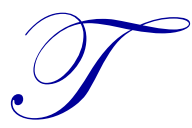

here is agreement in the literature (Maritz, 1995; Bass, 1997) that leadership is a critical factor in the success or failure of an organisation; excellent organisations begin with excellent leadership, and successful organisations reflect their leadership. Effective leadership can move organisations from current to future states, create visions of potential opportunities for organisations, instil within employees commitment to change and instil new cultures and strategies in organisations that mobilise and focus energy and resources (Bennis \& Nanus, 1985).

The benefits of organisational commitment have been well documented in the extant management literature (Davenport, 2010). Committed employees are less likely to develop patterns of tardiness or to be chronically absent from work (Davenport, 2010; Angle \& Perry, 1981; Bateman \& Strasser, 1984; Porter et al., 1974). Gbadamosi (2003) contends that the more favourable an individual's attitudes toward the organisation, the greater the individual's acceptance of the goals of the organisation, as well as their willingness to exert more effort on behalf of the organisation. Employees that are committed are also less likely to leave the organisation to explore other 
opportunities (Allen \& Meyer, 1996; Porter et al., 1974). Organisational commitment has also been shown to positively affect motivation, organisational citizenship, and job performance (Meyer et al., 2002; Mowday et al., 1974).

Accumulating evidence suggests that leadership style is positively associated with work attitudes and behaviours at both an individual and organisational level (Dumdum, Lowe \& Avolio, 2002). Correlation analysis shows that transformational and transactional leadership style is related to employees' organisational commitment (Marmaya et al, 2011). In particular, there is considerable research now available suggesting that transformational leadership is positively associated with organisational commitment in a variety of organisational settings and cultures (Guang-lu et al, 2012; Muterera, 2008; Avolio et al., 2004; Bono \& Judge, 2003; Walumbwa \& Lawler, 2003; Dumdum et al., 2002; Koh, Steers, \& Terborg, 1995; Lowe et al., 1996).

A major motivation for this study derives from the urgent challenge of attaining competitive advantage through the effective utilisation and retention of skilled knowledge workers in a multi-cultural South Africa. Various past studies cover different aspects of leadership and its relationship with organisational commitment (Sabir et al., 2011). Despite this, not enough empirical research studies on the drivers of organisational commitment amongst South African knowledge workers have been published (Bagraim, 2002; Kinnear, 2000). Shokane, Stanz and Slabbert, in 2004 undertook a study to describe the nature of leadership in South African organisations in pursuit of 'world class' competitive status. They concluded that the administrative nature of the public sector environment may be limiting the derivation of transformational leadership in the Public Sector Institution, and that the Tertiary Sector Institution is significantly a transformational organisation compared with the Private Sector Corporation and the Public Sector Institution.

Studies in organisational commitment in Australian and South African Accountants (Clayton \& Hutchinson, 2001), Secondary Education Educators in the Western Cape (Bull, 2005), Eskom Eastern Region (Nyengane, 2007), the South African Motor manufacturing industry (Manetje \& Martins, 2009), the telecommunications industry (Visagie, 2010), the accounting and information technology sector (Bagraim, 2010), and within the information technology environment ( Lumley et al, 2011) were conducted; however, studies within other Parastatal in South Africa are still to be concluded.

\section{LITERATURE REVIEW}

Various authors such as Stogdill (1974), Yukl (2009), Schilbach (1983), and others agree that leadership is a critical factor in the success or failure of an organisation; excellent organisations begin with excellent leadership and successful organisations reflect their leadership (Bass, 1994; 1997).

Three major leadership theories that have been developed over time are the trait theories, behavioural theories and situational/contingency theories. Each of these approaches describes different dimensions of leadership and their effects on the relationship between leaders and their followers. The following literature focuses on transformational and transactional leadership in specific.

\section{Transformational Leadership}

The term "Transformational Leadership", was originally coined by James Downton in a 1973 paper on rebel leadership, it was James MacGregor Burns who brought the term to wider parlance in his classic study of political leadership in the 1978 book simply entitled "Leadership" (Bryman, 2011). In recent years, there has been considerable interest in the model of transformational leadership, because it has been shown that transformational leaders generate greater commitment in their followers than do those who use other leadership styles (Avolio, 1999; Bass, 1998). Transformational leaders encourage problem solving in followers rather than constantly providing solutions and directions and a greater pool of knowledge (Buhler, 1995). Bass and Avolio (1994) suggest that a consequence of this behaviour is that followers develop the capacity to solve future problems which might be unforeseen by the leader. Dubinsky, Yammarino, Jolson and William (1995) also suggest that leaders who are intellectually stimulating often possess a high level of risk-taking because of their capability to trust the abilities of their followers. Individuals who work for transformational leaders may willingly expand their job descriptions as they develop a greater conception of the organisation as a whole (Avolio \& Bass, 1991). According to Bass and 
Avolio (2000), transformational leadership is defined by five key dimensions, i.e. Idealised influence attributes (refers to the socialised charisma of the leader, whereby the followers feel trust, admiration, loyalty and respect for the leader); Idealised influence behaviour (which refers to the charismatic actions of the leader, whereby individuals transcend their self-interest for the sake of the organisation and develop a collective sense of mission and purpose); Inspirational motivation (refers to the way in which transformational leaders energise their followers by articulating a compelling vision of the future - thus creating enthusiastic excitement, raising followers' expectations, and communicating confidence that followers can achieve ambitious goals); Intellectual stimulation (refers to the way in which transformational leaders question the status quo, appeal to followers' intellect, stimulate them to question their assumptions, and invite innovative and creative solutions to problems); and Individualised consideration (refers to leadership behaviour that contributes to follower satisfaction by paying close attention to the individual needs of followers, acting as a mentor or coach, and enabling them to develop and self-actualise).

Transformational leaders are thus characterised by: a) Raising the level of awareness of followers about the importance of achieving valued outcomes, a vision, and the required strategy; b) Getting followers to transcend their own self-interest for the sake of the team, organisation, or larger collectivity, and c) Expanding followers' portfolio of needs by raising their awareness to improve themselves and what they are attempting to accomplish (Burns, 1978; Bass, 1985b).

\section{Transactional Leadership}

In his seminal work on leadership, James MacGregor Burns (1978) defines transactional leadership as the first form of interaction between leaders and followers (Marturano \& Gosling, 2007). Bass (1985a) and Bass and Avolio (1997) described transactional leadership in terms of two characteristics: the use of contingent rewards and management by exception. They described contingent reward as the reward that the leader will bestow on the subordinate once the latter has achieved goals that were agreed to. Contingent reward is, therefore, the exchange of rewards for meeting agreed-on objectives. By making and fulfilling promises of recognition, pay increases and advancement for employees who perform well, the transactional leader is able to get things done. Bass (1985a) therefore argues that by providing contingent rewards, a transactional leader might inspire a reasonable degree of involvement, loyalty, commitment and performance from subordinates.

Transactional leaders may also rely on active management by exception which occurs when the leader monitors followers to ensure mistakes are not made, but otherwise, allows the status quo to exist without being addressed (Bass \& Avolio, 1997). In passive management by exception, the leader intervenes only when things go wrong (Nyengane, 2007). In general, one can conclude that transactional leadership is an exchange relationship that involves the reward of effort, productivity and loyalty.

Antonakis et al. (2003) stated that this leadership model is made up of the two first-order factors, i.e. Contingent Reward, and Management-by-Exception. Therefore, as Bass (1985a) contends, transactional leadership uses satisfaction of lower order needs as the primary basis for motivation. Accordingly, the focus in transactional leadership is on role clarification wherein the leader helps the follower in understanding exactly what needs to be done in order to meet the organisation's objectives and goals. Hence, a successful result of transactional leadership would be an expected outcome.

The full range of leadership, as measured by the Multifactor Leadership Questionnaire (MLQ), implies that every leader displays a frequency of both the transactional and transformational factors, but each leader's profile involves more of one and less of the other (Bass, 1999). Those leaders who are more satisfying to their followers and who are more effective as leaders are more transformational and less transactional (Avolio \& Bass, 1991).

\section{Leadership Style and Organisational Commitment}

The literature indicates that organisational commitment is linked to various variables, which include both personal variables such as age and gender, leadership style and trust. The literature also reveals that commitment entails a high level of identification with the organisation's goals and values, a willingness to exert extra effort for the benefit of the organisation and a strong desire to maintain membership in the organisation (Morrow, 1983). Organisational commitment has been identified as a useful measure of organisational effectiveness, because high 
levels of commitment can lead to several favourable organisational outcomes. Suliman and Iles (2000a) identify important aspects of organisational commitment, i.e. it fosters better superior-subordinate relationships; it enhances organisational development, growth and survival; it improves the work environment; it negatively influences withdrawal behaviour such as turnover, lateness and absenteeism; and it has a positive impact on employees' readiness to innovate and create.

Based on the different components of commitment, organisational commitment can be described as a multidimensional concept. According to Meyer and Allen (1997), organisational commitment can be classified into affective commitment (emotional attachment), continuance commitment (costs associated with leaving the organisation) and normative commitment (moral obligation to remain with the organisation).

The literature has shown that transactional and transformational leadership can get results from subordinates that are beyond expectations (Bass, 1997). Leaders can contribute to an employee's desire to remain committed to the organisation by inducing employees' trust and confidence in them. Bass (1990a) noted that the leadership research over the years has proved that loyalty is more powerful than tangible inducements. Price (1997) further suggests that employees are far more likely to be committed to the organisation, if they have confidence in their leader.

From a theoretical point of view, studies have shown that transformational leaders generally outperform transactional leaders in employee satisfaction, intellectual stimulation, and performance (Jung, 2001). Clearly, employee commitment reflects the quality of the leadership in the organisation (Stum, 1999). According to Nyengane (2007), it would be logical to assume that leadership style has a significant influence on the growth of an organisation.

In numerous studies, transformational leaders were found to generate higher commitment in their followers (Bass, 1998; Avolio, 1999; Avolio \& Yammarino, 2003). For instance, Koh, Terborg and Steers (1991) noted greater organisational commitment of school teachers and students if their principals were rated more transformational. Fuller, Patterson, Hester and Stringer (1996) reported in a meta-analysis, greater follower compliance if their leaders were more transformational than transactional.

Research, development and practical applications in the 25 years since Burns' (1978) significant publication on transforming leaders, has shown that transformational leadership generally generates greater follower effectiveness and satisfaction than does transactional leadership, although effective leaders certainly perform using the full range of styles (Avolio, 1999; Bass \& Avolio, 1993; Bass, 1985a, 1998). For example, Bass, Avolio, Jung \& Berson (2003), reported that for 72 U.S. light infantry platoon leaders, those who were rated higher on transformational leadership, led their platoons more effectively in near-combat readiness missions one month later.

Hayward, Goss and Tolmay (2004) noted that transformational leadership has a moderate positive correlation with affective commitment. Lower correlation coefficients between transformational leadership and normative and continuance commitment were also found. The findings have further indicated that no correlation was found between transactional leadership and affective, normative and continuance commitment.

Other researchers such as Kent and Chelladurai (2001) indicated that individualised consideration has a positive relationship with both affective commitment and normative commitment. Similarly, positive correlations were found between intellectual stimulation and both affective commitment and normative commitment.

Bass and Avolio (1994) revealed that transformational leaders who encourage their followers to think critically and creatively can have an influence on their followers' commitment. This is further supported by Walumbwa and Lawler (2003) that transformational leaders can motivate and increase followers' motivation and organisational commitment by getting them to solve problems creatively and also understanding their needs. Price (1997) further suggests that employees are far more likely to be committed to the organisation if they have confidence in their leaders. However, contingent reward behaviours that represent transactional leadership have been found to be reasonably associated with performance and work attitudes of followers although at a lower level than transformational leadership behaviours (Bass, 1990a; Bass \& Avolio, 1990c). 
Studies outside of the United States in diverse organisational settings revealed that context and contingencies were of importance as a source of variance in observations of transformational leadership, but the fundamental phenomena transcended organisations, cultures and countries (Bass, 1997). In Spain, Molero and Morales (1994) completed a study in 40 primary health care centres of the transformational leadership of the centre co-ordinators. They found that the leadership of the coordinators were more likely to be legitimate in the eyes of team members in those centres in which coordinators earned higher MLQ scores on each of the transformational factors. Team members found it was more acceptable for such coordinators to organise, manage, control and evaluate their performance. Role conflict was lower, interpersonal relations improved and a greater feeling of autonomy existed when the coordinators were seen as transformational.

In the Philippines, Catanyag (1995) observed that schools prepared their students more efficiently when school principals obtained higher transformational scores on the MLQ than the scores from teachers. In Austria, Geyer and Steyrer (1998) demonstrated that MLQ transformational ratings of 120 branch bank managers predicted long-term branch market share and customer satisfaction. In Canada, Howell and Avolio (1993) noted that the transformational, but not the transactional scores of department supervisors in a large Canadian financial institution predicted consolidated departmental performance one year later. Parallel findings were obtained in studies of managers in a Chinese state enterprise (Davis et al., 1997), Polish and Dutch managers (Den Hartog, 1997), and supervisors on North Sea oil platforms off of Scotland (Carnegie, 1995).

Lee (2005) found that transformational leadership correlates significantly with organisational commitment with samples of research and development professional in Singapore. He also noted that, transactional leadership did not have a significant relationship with organisational commitment.

In 2011, a study conducted by Alqudah (2011), noted that there was a strong positive relationship between the transformational leadership behaviours and organisational commitment in all three of its dimensions. Alqudah (2011) also noted that a weak but significant correlation exists between laissez-faire leadership and both affective and continuous commitment.

A few exceptions, however, were reported; for example, a study conducted by Dr Baloch and associates (2010) in Pakistan amongst 312 private sector college teachers, indicated that transformational leadership had 31\% impact on employees' commitment while transactional leadership $49 \%$ on employees' commitment. The result also indicates that the transactional leadership style is a stronger predictor of organisational commitment than transformational leadership style (Baloch et al., 2010). Similarly, a study conducted in Malaysia by Lo, Ramayah and Min (2009) titled, "Leadership styles and organizational commitment: a test on Malaysia manufacturing industry", concluded that there was a stronger impact on organisational commitment for transactional leadership styles, and that managers may anticipate lesser conflict between supervisors and general employees in organisations when employees' values reflect their culture, indicating a cultural bias to leadership and organisational commitment.

Avolio and Bass (1991) proposed a hierarchical ordering of leadership constructs with respect to their relationship with performance. They purported that transformational leadership would be most highly correlated with effectiveness followed by transactional and passive styles of leadership (passive management by exception and laissez-faire leadership). Their assumption has been confirmed in meta-analyses by Gaspar (1992), Fuller, Patterson, Hester and Stringer (1996), Lowe, Kroeck and Sivasubramaniam (1996), as well as Dumdum, Lowe and Avolio (2002).

In a South African study, Nyengane (2007) indicated that there is a positive relationship between transformational leadership behaviours and commitment. The correlation analysis also indicated a weak but significant positive relationship between transactional leadership behaviours and continuance commitment, which is in contrast to Lee's (2004) Singaporean study. Nyengane's (2007) correlation results also showed a weak but significant negative correlation between laissez-faire leadership behaviours and affective commitment.

\section{OBJECTIVES OF THE STUDY}

Various past studies cover different aspects of leadership and its relationship with organisational commitment (Sabir et al., 2011). The results from various studies are inconclusive. In addition, the influence of 
leadership style to employee commitment to the organisation has not been adequately addressed in the said Parastatal company in South Africa. Therefore, there is a need for greater understanding of the relationship between the leadership style and work-related attitudes (such as employee commitment) in order to develop a leadership style that will encourage organisational commitment. Thus, the main objective of the study was to establish the relationship between leadership styles and employee commitment at the said Parastatal company in South Africa.

In this study transactional leadership referred to a leader-follower relationship that is based on a series of exchanges or bargains between leaders and followers (Howell \& Avolio, 1993); in contrast, transformational leadership referred to a leader that goes beyond exchanging inducements for desired performance (Bass, 1985a) and involves stimulating followers to transcend their own self-interests for a higher collective purpose, mission, or vision (Bass, 1985a; Howell \& Avolio, 1993). Laissez-faire leadership, referred to the leader who is absent when needed, and who avoids making decisions (Bass \& Avolio, 2000).

From the identification of the broad objectives of the research, the specific hypothesis was formulated. The hypotheses were concerned with the relationship between the various leadership styles being practiced within the organisation and its influence on the various employee commitment styles. Therefore, the hypotheses (illustrated in Table 1) for this study were as follows:

$\mathbf{H}_{01}$ : There is no statistical significant relationship between transformational leadership and affective commitment to the organisation.

$\mathbf{H}_{\mathrm{a1}}$ : There is a statistical significant relationship between transformational leadership and affective commitment to the organisation.

$\mathbf{H}_{\mathbf{0 2}}$ : There is no statistical significant relationship between transformational leadership and continuance commitment to the organisation.

$\mathbf{H}_{\mathbf{a} 2}$ : There is a statistical significant relationship between transformational leadership and continuance commitment to the organisation.

$\mathbf{H}_{\mathbf{0 3}}$ : There is no statistical significant relationship between transformational leadership and normative commitment to the organisation.

$\mathbf{H}_{\mathrm{a} 3}$ : There is a statistical significant relationship between transformational leadership and normative commitment to the organisation.

$\mathbf{H}_{04}$ : There is no statistical significant relationship between transactional leadership and affective commitment to the organisation.

$\mathbf{H}_{\mathbf{a} 4}$ : There is a statistical significant relationship between transactional leadership and affective commitment to the organisation.

$\mathbf{H}_{05}$ : There is no statistical significant relationship between transactional leadership and continuance commitment to the organisation.

$\mathbf{H}_{\mathrm{a} 5}$ : There is a statistical significant relationship between transactional leadership and continuance commitment to the organisation.

$\mathbf{H}_{\mathbf{0 6}}$ : There is no statistical significant relationship between transactional leadership and normative commitment to the organisation.

$\mathbf{H}_{\mathrm{a} 6}: \quad$ There is a statistical significant relationship between transactional leadership and normative commitment to the organisation.

$\mathbf{H}_{\mathbf{0 7}}$ : There is no statistical significant relationship between laissez-faire leadership and affective commitment to the organisation.

$\mathbf{H}_{\mathbf{a} 7}$ : There is a statistical significant relationship between laissez-faire leadership and affective commitment to the organisation.

$\mathbf{H}_{\mathbf{0 8}}$ : There is no statistical significant relationship between laissez-faire leadership and continuance commitment to the organisation.

$\mathbf{H}_{\mathrm{a}}$ : $\quad$ There is a statistical significant relationship between laissez-faire leadership and continuance commitment to the organisation.

$\mathbf{H}_{\mathbf{0}}$ : $\quad$ There is no statistical significant relationship between laissez-faire leadership and normative commitment to the organisation.

$\mathbf{H}_{\mathbf{a} 9}: \quad$ There is a statistical significant relationship between laissez-faire leadership and normative commitment to the organisation. 
Table 1: Tabulated Hypotheses of Leadership versus Commitment

\begin{tabular}{|c|c|c|c|c|c|c|c|}
\hline & $\begin{array}{c}\text { Transformational } \\
\text { Leadership }\end{array}$ & $\begin{array}{l}\text { Transactional } \\
\text { Leadership }\end{array}$ & $\begin{array}{c}\text { Laissez-Faire } \\
\text { Leadership }\end{array}$ & $\begin{array}{c}\text { Affective } \\
\text { Commitment }\end{array}$ & $\begin{array}{l}\text { Continuance } \\
\text { Commitment }\end{array}$ & $\begin{array}{c}\text { Normative } \\
\text { Commitment }\end{array}$ & \\
\hline $\begin{array}{c}\text { Transformational } \\
\text { Leadership }\end{array}$ & & & & $\mathrm{H}_{\mathrm{a} 1}$ & $\mathrm{H}_{\mathrm{a} 2}$ & $\mathrm{H}_{\mathrm{a} 3}$ & \multirow{3}{*}{$\begin{array}{c}\text { Statistical } \\
\text { Significant } \\
\text { Relationship }\end{array}$} \\
\hline $\begin{array}{c}\text { Transactional } \\
\text { Leadership }\end{array}$ & & & & $\mathrm{H}_{\mathrm{a} 4}$ & $\mathrm{H}_{\mathrm{a} 5}$ & $\mathrm{H}_{\mathrm{a} 6}$ & \\
\hline $\begin{array}{c}\text { Laissez-Faire } \\
\text { Leadership }\end{array}$ & & & & $\mathrm{H}_{\mathrm{a} 7}$ & $\mathrm{H}_{\mathrm{a} 8}$ & $\mathrm{H}_{\mathrm{a} 9}$ & \\
\hline $\begin{array}{c}\text { Affective } \\
\text { Commitment } \\
\end{array}$ & $\mathrm{H}_{01}$ & $\mathrm{H}_{04}$ & $\mathrm{H}_{07}$ & & & & \multirow{3}{*}{$\begin{array}{l}\text { No Statistica } \\
\text { Significant } \\
\text { Relationship }\end{array}$} \\
\hline $\begin{array}{l}\text { Continuance } \\
\text { Commitment }\end{array}$ & $\mathrm{H}_{02}$ & $\mathrm{H}_{05}$ & $\mathrm{H}_{08}$ & & & & \\
\hline $\begin{array}{c}\text { Normative } \\
\text { Commitment }\end{array}$ & $\mathrm{H}_{03}$ & $\mathrm{H}_{06}$ & $\mathrm{H}_{09}$ & & & & \\
\hline
\end{tabular}




\section{RESEARCH DESIGN AND METHODOLOGY}

The study followed the following steps:

Firstly, the research method was determined based on the literature review, and on previous research undertaken, in order to compare results. Secondly, the population was determined for this research to be the entire staff component of the company, and the sampling was determined using "EpiInfo"; a statistical program that determines the required sample based on the entire population. It was assumed that if the worst acceptable result was a minimum of $80 \%$ (worst case scenario), then a response rate of 26 managers and 32 subordinates will be required for a 95\% confidence level. Data collection would therefore be complete when 26 managers and 32 subordinates' forms have been handed in. Thirdly, the Multifactor Leadership Questionnaire (MLQ) and Organisational Commitment Questionnaire (OCQ) were selected. Fourthly, the questionnaires were distributed randomly, and the data collected. Fifthly, data was captured using Microsoft Excel, and finally data statistical analysis was done using Stata.

\section{Sample Size}

The targeted population for this study was the Parastatal staff comprising professionals (managers, engineers and technicians) and their subordinates. For the purpose of this study, out of a population of 102 managers, a sample of 58 was randomly drawn to achieve a confidence level of $99 \%$ (as calculated using "Epi Info"). As shown in Table 2, 34 managers successfully completed and returned the questionnaires, resulting in a response rate of 59\%. Only 26 responses were required for a confidence level of $95 \%$.

Table 2: Population, Sample and Responses Rates

\begin{tabular}{|l|c|c|}
\hline & Managers & Subordinates \\
\hline Population & 102 & 538 \\
\hline Sample & 58 & 290 \\
\hline Responses & 34 & 163 \\
\hline
\end{tabular}

In order to obtain a holistic view of the overall leadership style present in the organisation, three or more subordinates (per randomly selected manager) were also randomly selected for the administration of the rater version of the Multifactor Leadership Questionnaire. A sample of 290 subordinates was targeted from a population of approximately 538 for a required confidence level of 99\% (as determined by "Epi Info"). A total of 163 questionnaires were completed and returned, resulting in a response rate of 56\%. Only 108 responses were required for a confidence level of $95 \%$. The total number of responses analysed, including leaders and their corresponding rater, were 197.

\section{Measuring Instruments}

Two questionnaires were used in this research to obtain information on leadership and organisational commitment, respectively, namely the Multifactor Leadership Questionnaire (MLQ) and Organisational Commitment Questionnaire (OCQ).

Multifactor Leadership Questionnaire [MLQ]

The MLQ was formulated from the Full Range Leadership Development Theory (Bass \& Avolio, 1997), and has been improved and tested since 1985 with the result that many versions of the questionnaire have been developed. The latest version, Form 5X (Revised), was used in this study. The MLQ has been tested for reliability and validity in a number of settings (Pruijn \& Boucher, 1994). Not only has the MLQ been tested in the international context (Bass \& Avolio, 1997) but also in the South African context (Ackerman et al., 2000). It has proven to be a strong predictor of leader performance across a broad range of organisations (Bass \& Avolio, 1997; Tonelli, 2008). The results of these test-retest studies indicate that the components of transformational, transactional and nontransactional leadership are reliably measured by the MLQ (Bass \& Avolio, 1997; Hayward, 2005). The Full Range Leadership Development Theory is a suitable theoretical construct of leadership (Bass \& Avolio, 1997; Sosik \& Jung, 2012). However reliability of this instrument was tested in this study and average Cronbach's alpha reliability 
coefficient for the questionnaire used was 0.973 (see Annexure I - available from the author upon request), which according to Nunnally and Bernstein (1994), are desirable.

In this study, leaders completed the Self-Rater MLQ, by rating themselves in terms of the transformational, transactional or laissez-faire leadership factors. Subordinates completed the Rater version of the same questionnaire. The leaders were rated in terms of the same criteria on which they rated themselves. In order to gain an accurate picture of the leader's ability, the Rater MLQ was completed by three or more respondents (Bass, 1985b). Examples of items from the transformational, transactional and laissez-faire leadership are shown in Table 3 below:

Table 3: Items from the Transformational, Transactional and Laissez-Faire Leadership Styles

\begin{tabular}{|c|c|}
\hline Transformational Leadership & Example \\
\hline Idealised influence (attributed) & I instil pride in others for being associated with me. \\
\hline Idealised influence (behaviour) & I specify the importance of having a strong sense of purpose. \\
\hline Inspirational motivation & I talk optimistically about the future. \\
\hline Individualised consideration & I spend time teaching and coaching. \\
\hline Intellectual stimulation & I re-examine critical assumptions for appropriateness. \\
\hline \multicolumn{2}{|l|}{ Transactional Leadership } \\
\hline Contingent rewards & I provide others with assistance in exchange for their efforts. \\
\hline Management-by-exception-active & I focus attention on irregularities, mistakes, exceptions and deviations from standards. \\
\hline Management-by-exception-passive & I fail to interfere until problems become serious. \\
\hline \multicolumn{2}{|l|}{ Laissez-Faire } \\
\hline Laissez-faire & I avoid getting involved when important issues arise. \\
\hline
\end{tabular}

Organisational Commitment Questionnaire [OCQ]

Meyer and Allen (1984) initially distinguished between two types of commitment: affective commitment and continuance commitment. Affective commitment denoted a sense of belonging and emotional attachment to the organisation, whereas continuance commitment emphasised the perceived costs of leaving the organisation. Allen and Meyer (1990) subsequently introduced a third component of commitment, normative commitment, which reflected the perceived obligation to remain with the organisation. They created a pool of 51 items for the scale. The scale was tested with approximately 500 employees from two manufacturing firms and a university. Clerical, managerial and supervisory employees were represented in the sample. Females represented 57 percent of the sample. Scale items for measuring affective, normative and continuance commitment were selected for inclusion in the scales based on a series of decision rules that took into consideration item endorsement proportions, item-total correlations, direction of scoring and content redundancy (Allen \& Meyer, 1990). Later, Meyer, Allen and Smith (1993) revised the normative commitment scale to clarify the distinction between affective commitment and normative commitment. While the earlier versions (Allen \& Meyer, 1990; Meyer \& Allen, 1984; 1991) of the OCQ contained 24 items (8 items for each scale), the later version by Meyer and Allen (1997) as well as Meyer, Allen and Smith (1993) only contained 18 items (6 items for each scale). In this study, the affective, continuance and normative commitment of employees were assessed through the administration of Bagraim's (2004) adaptation of Meyer and Allen's (1997) 18 items' three-dimensional commitment measure. Several studies have been conducted to examine the reliability (Cronbach's Alpha coefficient) of the OCQ. These results showed that the three commitment constructs could be reliably measured. This OCQ instrument has also been shown to have validity across various cultural contexts and has been regarded as a measure of turnover intention.

This study found the average Cronbach's alpha reliability coefficient for the OCQ instrument to be 0.94 , which is good. The individual factors for the OCQ namely; Affective commitment, Normative Commitment and Continuance commitment had alpha scores of $0.91,0.90$ and 0.89 respectively. Therefore, for this research, the OCQ instrument was a reliable measure of affective commitment, continuance commitment and normative commitment.

\section{Study Variables}

Responses to research statements were scaled and converted to quantitative data via a code manual developed by Bass and Avolio (1991) for the MLQ and Allen and Meyer (1990) for the OCQ, to enable segmentation of the data responses into various variables based on leadership behaviours and associated 
performance variables. Table 4 lists the variables that were part of this study. Three separate sub-variables of organisational commitment were used. These sub-variables were the affective commitment scale, continuance commitment scale and normative commitment scale of the OCQ. Sub-variables measuring Full Range Leadership behaviours were considered separately. The sub-variables for these variables are Idealised Influence (Attributed), Idealised Influence (Behaviour), Inspirational Motivation, Intellectual Stimulation, Individualised Consideration, Contingent Reward, Management-by-exception (Active), Management-by-exception (Passive) and Laissez-faire.

Table 4: Study Variables

\begin{tabular}{|c|c|c|c|}
\hline Instrument & Variables & Sub-Variables & Indicators \\
\hline \multicolumn{4}{|c|}{ Variables for Organisational Commitment } \\
\hline \multirow{3}{*}{$\begin{array}{l}\text { Organisational Commitment } \\
\text { Questionnaire }\end{array}$} & \multirow{3}{*}{$\begin{array}{l}\text { Organisational } \\
\text { Commitment }\end{array}$} & Affective Commitment & Questions 1, 4, 9, 10 \\
\hline & & Continuance Commitment & Questions 7, 8, 11, 12 \\
\hline & & Normative Commitment & Questions 2, 3, 5,6 \\
\hline \multicolumn{4}{|l|}{ Variables for Leadership } \\
\hline \multirow{9}{*}{$\begin{array}{l}\text { Multifactor Leadership } \\
\text { Questionnaire }\end{array}$} & \multirow{5}{*}{$\begin{array}{c}\text { Transformational } \\
\text { Leadership }\end{array}$} & Idealised Influence (Attributed) & Questions 10, 18, 21, 25 \\
\hline & & Idealised Influence (Behaviour) & Questions 6, 14, 23, 34 \\
\hline & & Inspirational Motivation & Questions $9,13,26,36$ \\
\hline & & Intellectual Stimulation & Questions 2, 8, 30, 32 \\
\hline & & Individual Consideration & Questions 15, 19, 29, 31 \\
\hline & \multirow{3}{*}{$\begin{array}{l}\text { Transactional } \\
\text { Leadership }\end{array}$} & Contingent Reward & Questions 1, 11, 16, 35 \\
\hline & & $\begin{array}{l}\text { Management-by-exception } \\
\text { (Active) }\end{array}$ & Questions 4, 22, 24, 27 \\
\hline & & $\begin{array}{c}\text { Management-by-exception } \\
\text { (Passive) }\end{array}$ & Questions 3, 12, 17, 20 \\
\hline & Laissez-Faire & Laissez-Faire & Questions 5, 7, 28, 33 \\
\hline
\end{tabular}

\section{Data Collection}

For the purposes of this research, the questionnaires were used to gather the necessary information. In an attempt not to disrupt business operations and to ensure that the respondents would receive the documents in the shortest possible time, questionnaires were distributed through the internal mailing system. Each questionnaire was accompanied by a further covering letter explaining the purpose of the study to the prospective respondent. This technique of data collection addressed issues of cost, time and geographical constraints.

In both measuring instruments, the respondents were informed that they will be allowed to leave a question/answer blank if the question appeared unclear or ambiguous. Contact details were provided on the covering letter, offering the manager and employees the opportunity to contact the researcher in the event of any queries or problems that may arise. The covering letter requested the respondents to return the questionnaire and answer sheet, via the internal mailing system or hand deliver, to the researcher.

Once the questionnaires had been completed, the authors then coded the responses in each questionnaire. These scores were captured in a Microsoft Excel spreadsheet for statistical analysis with respect to Leader, Rater, and Organisational Commitment; were then exported into STATA (data analysis software) for analysis. 


\section{ANALYSIS OF RESULTS}

\section{Leadership Scores}

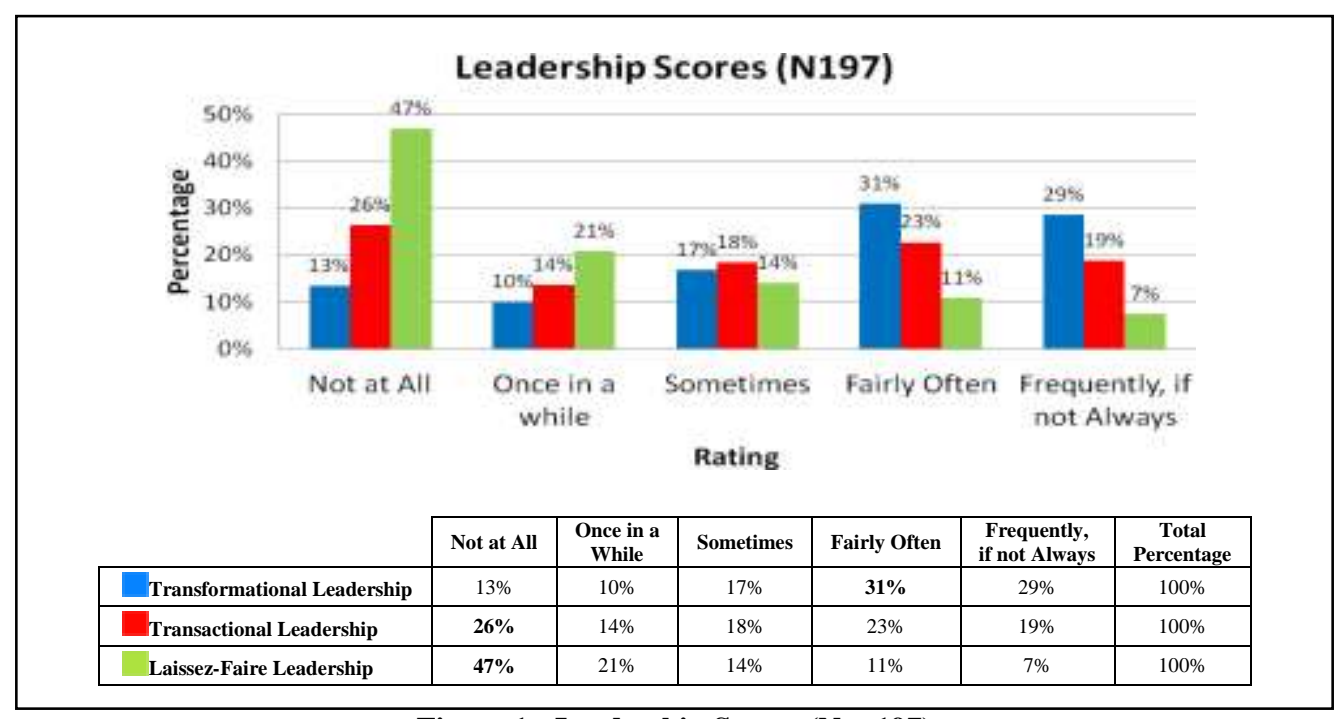

Figure 1: Leadership Scores $(\mathbf{N}=197)$

From Figure 1, the total respondents, being subordinates and managers, rated $31 \%$ organisational leadership as 'Fairly Often' as Transformational, while only $26 \%$ regarded leadership 'Not at All' as Transactional. A majority of employees (47\%) regarded leadership as not being laissez-faire. The mean and standard deviation of each variable are detailed in Table 5 below:

Table 5: Sample Sizes, Mean Scores and Standard Deviations for the Leadership Style Dimensions (N = 197)

\begin{tabular}{|l|c|c|c|c|c|c|c|}
\hline \multicolumn{1}{|c|}{ Dimension } & Code & $\begin{array}{c}\text { Valid } \\
\mathbf{N}\end{array}$ & Mean & $\begin{array}{c}\text { Modal } \\
\text { Freq. }\end{array}$ & $\begin{array}{c}\text { Standard } \\
\text { Deviation }\end{array}$ & \multicolumn{2}{c|}{$\begin{array}{c}\text { Bass \& Avolio (1997) } \\
\text { Suggested Range }\end{array}$} \\
\hline & & & & & & $\begin{array}{c}\text { International } \\
\text { South African } \\
\text { Average }\end{array}$ \\
\hline Idealised influence (attributed) & IA & 197 & 2.65 & 4 & 1.12 & 3 & 2.97 \\
\hline Idealised influence (behaviour) & IB & 197 & 2.48 & 3 & 1.09 & 3 & 2.99 \\
\hline Inspirational motivation & IM & 197 & 2.68 & 3 & 1.16 & 3 & 3.04 \\
\hline Individualised consideration & IC & 197 & 2.35 & 4 & 1.17 & 3 & 3.09 \\
\hline Intellectual stimulation & IS & 197 & 2.53 & 3 & 1.07 & 3 & 2.97 \\
\hline Transformational Leadership & TF & $\mathbf{1 9 7}$ & $\mathbf{2 . 5 3}$ & $\mathbf{3}$ & $\mathbf{1 . 0 5}$ & $\mathbf{3}$ & $\mathbf{3 . 0 1}$ \\
\hline Contingent rewards & CR & 197 & 2.46 & 4 & 1.15 & 2 & 3.03 \\
\hline Management-by-exception-active & MBEA & 197 & 2.14 & 3 & 1.02 & $1-2$ & 2.31 \\
\hline Management-by-exception-passive & MBEP & 197 & 1.21 & 0 & 0.94 & 1 & 1.09 \\
\hline Transactional Leadership & TA & $\mathbf{1 9 7}$ & $\mathbf{1 . 9 3}$ & $\mathbf{0}$ & $\mathbf{0 . 5 6}$ & $\mathbf{1 - 2}$ & $\mathbf{2 . 1 4}$ \\
\hline Laissez Faire & LF & $\mathbf{1 9 7}$ & $\mathbf{1 . 1 1}$ & $\mathbf{0}$ & $\mathbf{0 . 9 8}$ & $\mathbf{0}$ & $\mathbf{0 . 6 7}$ \\
\hline
\end{tabular}

Table 5, contains descriptive data for the five transformational leadership subscales, three transactional subscales, and one laissez-faire subscale. The distribution of scores for the sample contained reasonable variance and normality for use in subsequent analyses. All leadership variables hold a sample size of 197, while all commitment variables, where leaders did not rate themselves (reported in Table 6), have a sample size of 163, indicating that there are no visible inconsistencies in the capturing of the data. The mean values for each of the transformational leadership subscales are all relatively close to 2.5 except Individualised consideration, and those for transactional leadership ranges from 1.21 to 2.46 . The mean values for laissez-faire is 1.11 . The greatest standard deviation in the leadership factors is individualised consideration which attained approximately 1.17 standard deviation scores with Inspirational motivation a close second. The standard deviation of the variables are relatively high, indicating a wide spread of responses. 
The Modal frequency as per Table 5, for Idealised Influence (attributed), Individualised Consideration and Contingent Reward was on average 4 indicating that both raters and leaders felt that these attributes were "frequently if not always" displayed. Whilst attributes of Idealised Influence (behaviour), Inspirational Motivation, Intellectual Stimulation, and Management-by-exception (active) were rated on average as 3 indicating that they were "fairly often" displayed. Attributes that were on average indicated as "not at all" displayed were: Management-byexception (passive) and Laissez-faire.

For the most effective leadership, Bass and Avolio (1997) suggest mean scores of greater or equal to 3.0 for Individualised Consideration, Intellectual Stimulation, Idealised Influence (Behaviour), Idealised Influence (Attributed) and Inspirational Motivation. The overall scores of leadership subscales obtained in this study (2.35, 2.53, 2.48, 2.65 and 2.68, respectively) are slightly less than what Bass and Avolio (1997) suggested, they are also less than the average scores obtained from South African studies. This implies that managers are not displaying the ideal levels of transformational leadership.

Bass and Avolio (1997) also suggested a mean score of 2 for contingent reward, which is lower-than the current study's mean score of 2.46. The suggested range for management-by-exception (active) was 1.0 to 2.0 and the mean score obtained for the current study was 2.14 , which is slightly outside the range. Suggested scores for management-by-exception (passive) and laissez-faire are 1.0 and 0.0 ; however, mean scores for the current study were 1.21 and 1.11, respectively. This indicated a greater level of transactional and laissez-faire behaviours exhibited by managers.

The reference ranges for South African studies indicate values of 3.03 for Contingent Reward, 2.31 for Management by exception (Active), 1.09 for Management by exception (Passive) and 0.67 for Laissez-faire. Contingent Reward and Management by exception (active) mean scores are below the South African average, whilst Management by exception (Passive) and Laissez-faire mean values are significantly higher.

These scores in Table 5 suggest that managers are not displaying the ideal suggested levels of transformational leadership behaviours. These behaviours included engendering trust, inspiring a shared vision, generating enthusiasm, encouraging creativity and providing coaching. The mean for contingent reward suggests that some employees perceived their immediate managers as doing an above average job of clarifying expectations and recognising accomplishments when compared to the international reference mean. This was also the case for the management-by-exception (active) mean, which implies that some employees perceived their immediate managers as taking corrective action in a timely manner. Mean scores for management-by-exception (passive) and laissez-faire suggests managers tended to wait too long before resolving a problem or taking corrective action.

\section{Organisational Commitment Scores}

In Figure 2, 30\% of raters or general employees, viewed their commitment 'Sometime' as Affective whilst $25 \%$ ascertained their commitment 'Fairly Often' as Normative. Only $24 \%$ of raters or general employees rated their commitment 'Fairly Often' as Continuance.

Meyer and Allen (1997) do not provide guidance about expected, desired, average or ideal means for organisational commitment scales (namely affective, continuance, and normative commitment). Instead, they and other researchers (Allen \& Meyer, 1996; Dunham, Grube \& Castaneda, 1994) examined whether there was a positive or negative relationship between the different types of organisational commitment, the outcomes that are being measured, as well as the pattern for those findings. The desired pattern is having the highest scores for affective commitment, followed by normative commitment and then continuance commitment. 


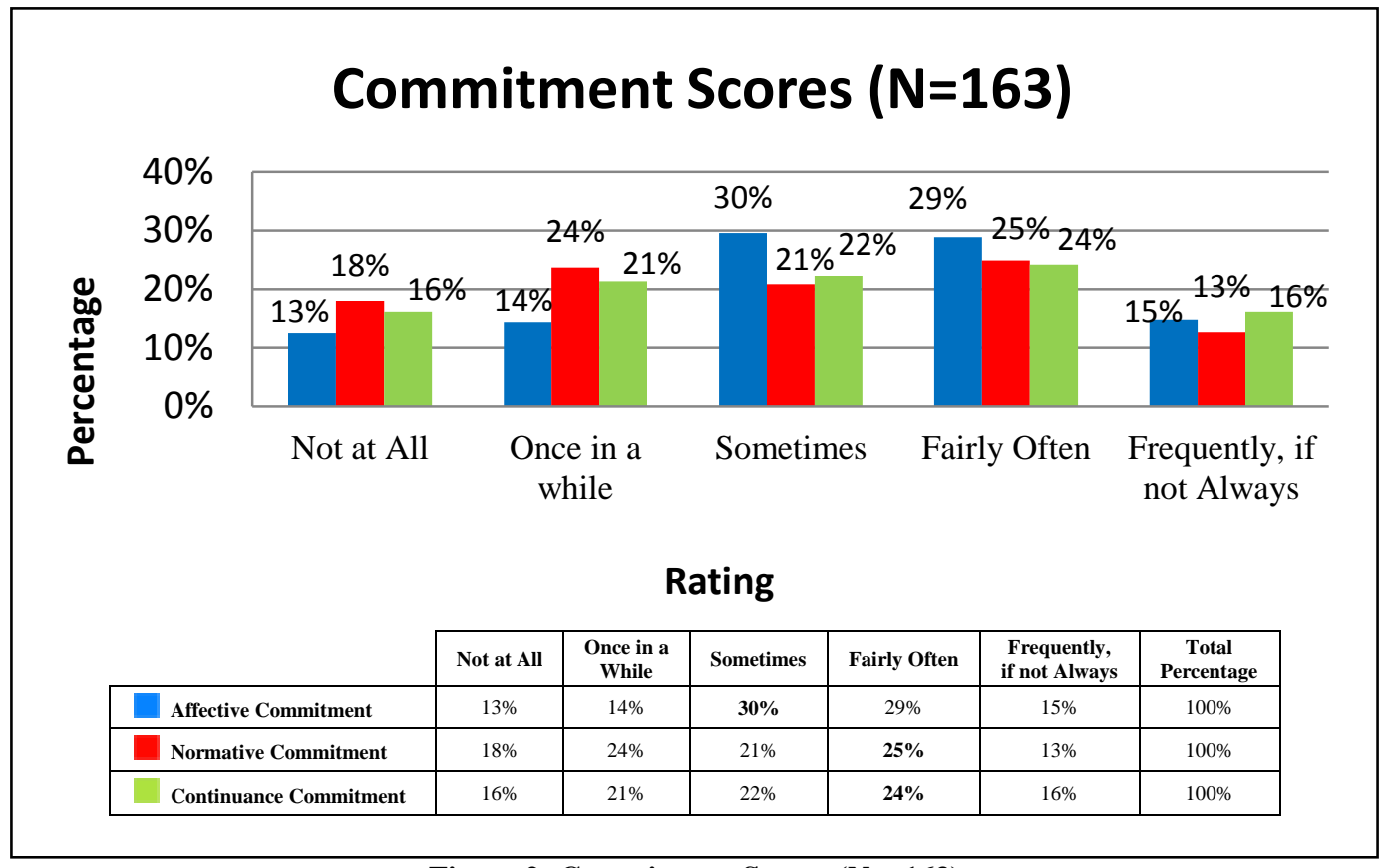

Figure 2: Commitment Scores $(\mathbf{N}=163)$

Table 6: Sample Sizes, Mean Scores and Standard Deviations for Organisational Commitment Dimensions

\begin{tabular}{|l|c|c|c|c|c|}
\hline \multicolumn{1}{|c|}{ Dimension } & Code & $\begin{array}{c}\text { Valid } \\
\mathbf{N}\end{array}$ & Mean & $\begin{array}{c}\text { Modal } \\
\text { Frequency }\end{array}$ & Standard Deviation \\
\hline Affective Commitment & $\mathrm{AC}$ & 163 & 2.19 & 2 & 1.23 \\
\hline Continuance Commitment & $\mathrm{CC}$ & 163 & 2.03 & 3 & 1.33 \\
\hline Normative Commitment & $\mathrm{NC}$ & 163 & 1.91 & 3 & 1.31 \\
\hline Organisational Commitment & OC & $\mathbf{1 6 3}$ & $\mathbf{2 . 0 5}$ & $\mathbf{3}$ & $\mathbf{1 . 2 9}$ \\
\hline
\end{tabular}

All commitment variables had a sample size of 163. The mean scores indicated in Table 6 for affective commitment was 2.19, which is significantly higher than normative commitment at 1.91. Table 6 also indicates mean scores for continuance commitment which are slightly higher than those for normative commitment. The mean scores indicate the pattern postulated by Allen and Meyer (1996).

The modal frequency for commitment was on average 3 (agree) for Continuance Commitment, Normative Commitment and Organisational Commitment as a whole. Raters were neutral with regard to Affective Commitment, rating and average 2 .

\section{Relationship}

\section{Comparisons between Leader and Employee Responses}

Leaders rated themselves higher in Transformational Leadership and Transactional Leadership compared to the raters (subordinates) (Figure 3 and Figure 4). 44\% of all Leaders rated themselves "Fairly Often" as transformational, whilst only $28 \%$ of raters (subordinates) rated their managers "Fairly Often" as transformational (Figure 3). 23\% of Leaders indicated that they displayed transactional leadership "Not at All", whilst 27\% of their subordinates indicated that their managers did not display any form of transactional leadership (Figure 4). 58\% of Leaders indicated that they did "Not at All" display laissez-faire leadership, and 44\% of raters agreed (Figure 5). 


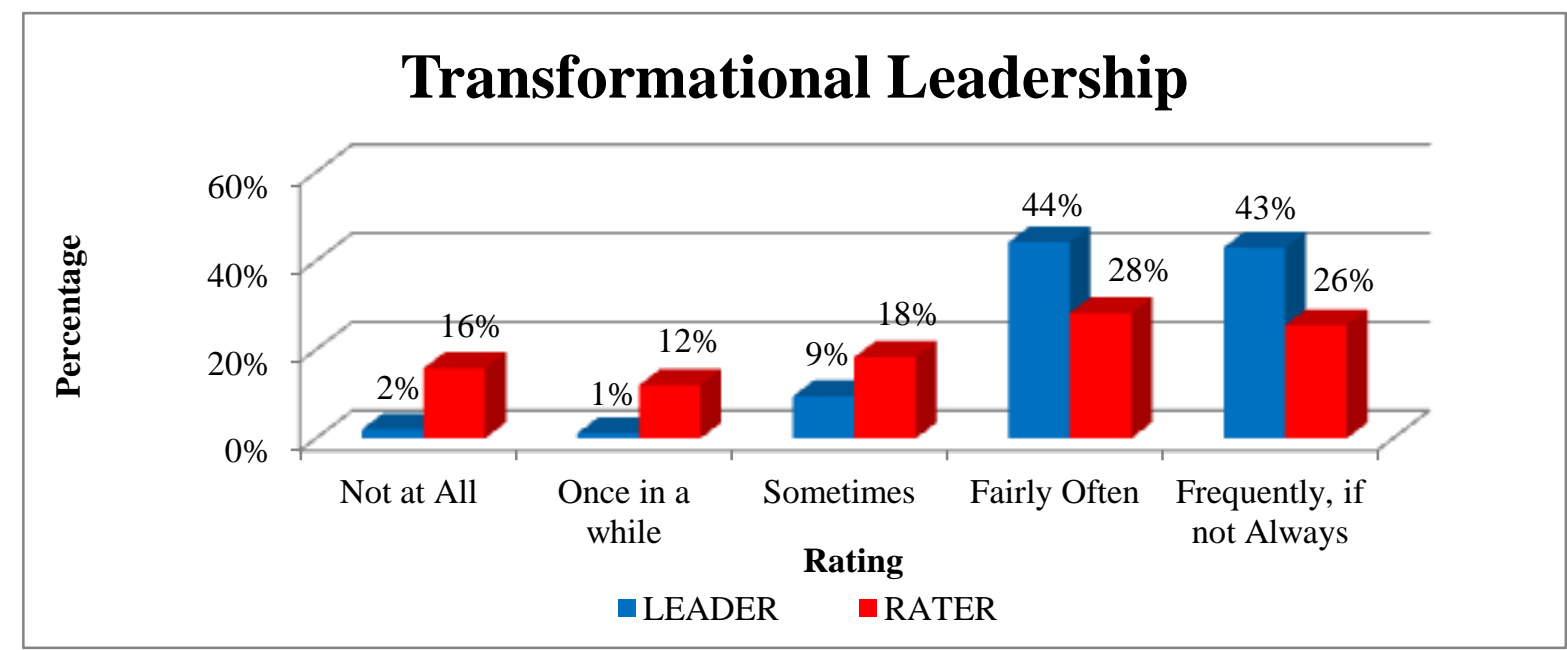

Figure 3: Transformational Leadership (Leader versus Rater)

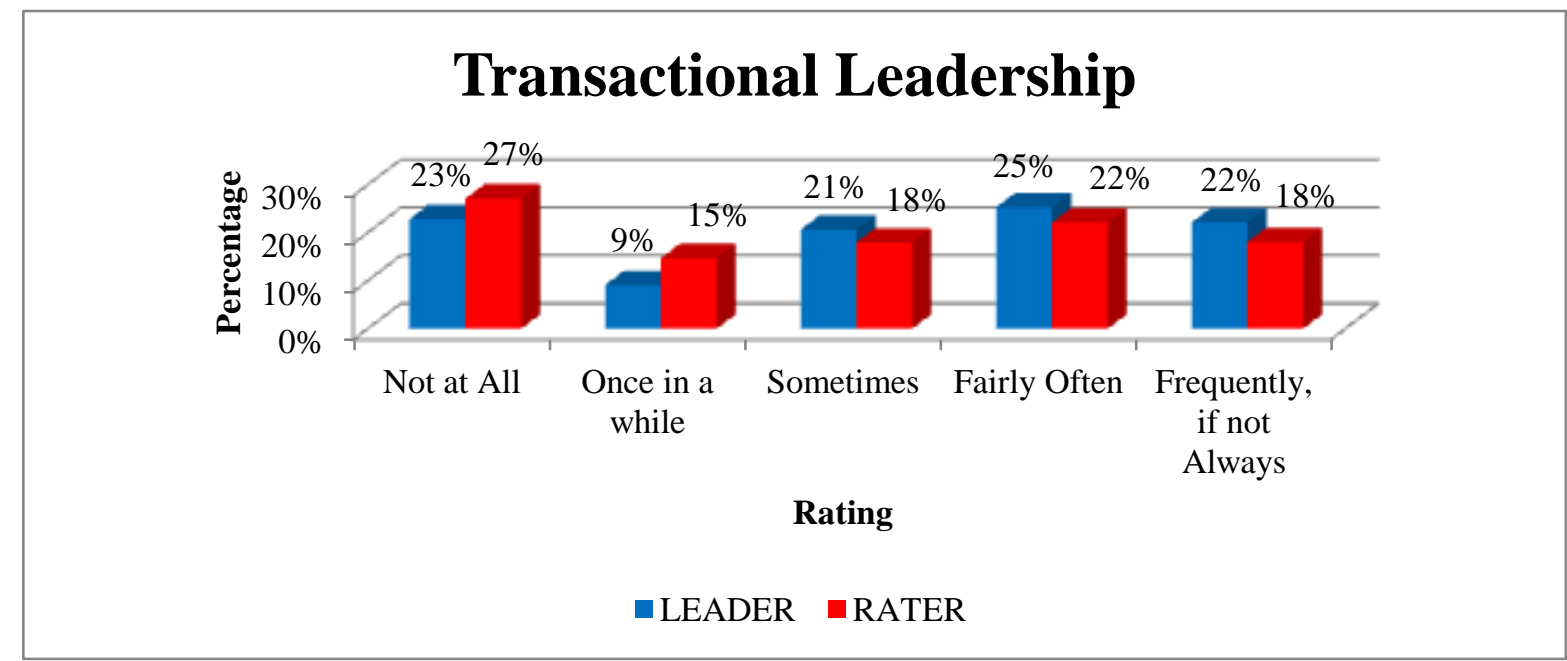

Figure 4: Transactional Leadership (Leader versus Rater)

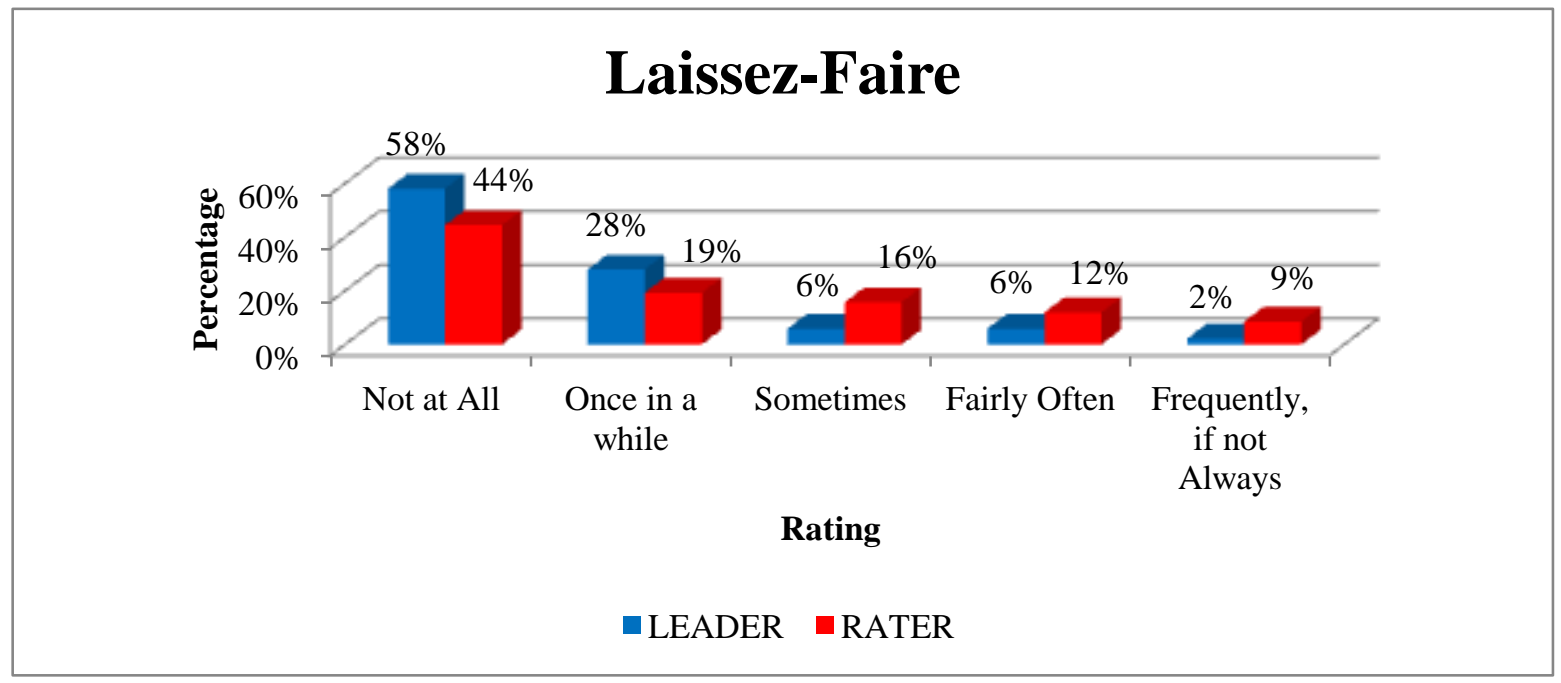

Figure 5: Laissez-Faire Leadership (Leader versus Rater) 
T-tests were used to compare the means of the two samples (independent). In this case, the significant differences, between the two samples on the dimensions of the questionnaires, were determined. The tests carried two critical assumptions regarding data distribution. The first assumption was that the values in the data set were independent (measured on randomly selected units from the study area). The second was that the data was normally distributed. The results are presented in Table 7.

Table 7: T-Tests Results for the MLQ (Leaders and Employees) Responses

\begin{tabular}{|c|c|c|c|c|c|c|c|}
\hline Variable & Group & $\mathbf{N}$ & Mean & $\begin{array}{l}\text { Standard } \\
\text { Deviation }\end{array}$ & $\begin{array}{l}\text { Weighted } \\
\text { Mean }\end{array}$ & & $\mathbf{T}$ \\
\hline \multirow{2}{*}{$\begin{array}{l}\text { Idealised influence } \\
\text { (attributed) (IA) }\end{array}$} & Leader & 34 & 3.33 & 0.47 & \multirow{2}{*}{2.65} & Equal Variance Assumed & $4.04 *$ \\
\hline & Rater & 163 & 2.51 & 1.17 & & Equal Variance not Assumed & $6.73 *$ \\
\hline \multirow{2}{*}{$\begin{array}{l}\text { Idealised influence } \\
\text { (behaviour) (IB) }\end{array}$} & Leader & 34 & 3.29 & 0.45 & \multirow{2}{*}{2.48} & Equal Variance Assumed & $5.02 *$ \\
\hline & Rater & 163 & 2.32 & 1.11 & & Equal Variance not Assumed & $8.40 *$ \\
\hline \multirow{2}{*}{$\begin{array}{l}\text { Inspirational motivation } \\
\text { (IM) }\end{array}$} & Leader & 34 & 3.41 & 0.44 & \multirow{2}{*}{2.68} & Equal Variance Assumed & $4.24 *$ \\
\hline & Rater & 163 & 2.52 & 1.20 & & Equal Variance not Assumed & $7.36 *$ \\
\hline \multirow{2}{*}{$\begin{array}{l}\text { Individualised } \\
\text { consideration (IC) }\end{array}$} & Leader & 34 & 3.37 & 0.42 & \multirow{2}{*}{2.35} & Equal Variance Assumed & $6.05^{*}$ \\
\hline & Rater & 163 & 2.14 & 1.16 & & Equal Variance not Assumed & $10.53 *$ \\
\hline \multirow{2}{*}{ Intellectual stimulation (IS) } & Leader & 34 & 3.22 & 0.38 & \multirow{2}{*}{2.53} & Equal Variance Assumed & $4.33 *$ \\
\hline & Rater & 163 & 2.39 & 1.11 & & Equal Variance not Assumed & $7.68 *$ \\
\hline \multirow{2}{*}{$\begin{array}{l}\text { Transformational leadership } \\
\text { (TF) }\end{array}$} & Leader & 34 & 3.32 & 0.34 & \multirow{2}{*}{2.53} & Equal Variance Assumed & $5.14 *$ \\
\hline & Rater & 163 & 2.37 & 1.07 & & Equal Variance not Assumed & $9.39 *$ \\
\hline \multirow[b]{2}{*}{ Contingent rewards (CR) } & Leader & 34 & 3.15 & 0.53 & \multirow[b]{2}{*}{2.46} & Equal Variance Assumed & $3.99 *$ \\
\hline & Rater & 163 & 2.32 & 1.19 & & Equal Variance not Assumed & $6.37 *$ \\
\hline \multirow{2}{*}{$\begin{array}{l}\text { Management-by-exception- } \\
\text { active (MBEA) }\end{array}$} & Leader & 34 & 2.27 & 0.98 & \multirow{2}{*}{2.14} & Equal Variance Assumed & 0.82 \\
\hline & Rater & 163 & 2.11 & 1.03 & & Equal Variance not Assumed & 0.85 \\
\hline \multirow{2}{*}{$\begin{array}{l}\text { Management-by-exception- } \\
\text { passive (MBEP) }\end{array}$} & Leader & 34 & 1.01 & 0.75 & \multirow{2}{*}{1.21} & Equal Variance Assumed & -1.38 \\
\hline & Rater & 163 & 1.26 & 0.97 & & Equal Variance not Assumed & -1.64 \\
\hline \multirow{2}{*}{$\begin{array}{l}\text { Transactional leadership } \\
\text { (TA) }\end{array}$} & Leader & 34 & 2.14 & 0.53 & \multirow{2}{*}{1.93} & Equal Variance Assumed & $2.45 *$ \\
\hline & Rater & 163 & 1.89 & 0.56 & & Equal Variance not Assumed & $3.99 *$ \\
\hline \multirow{2}{*}{ Laissez-faire (LF) } & Leader & 34 & 0.66 & 0.71 & \multirow{2}{*}{1.11} & Equal Variance Assumed & $-2.98 *$ \\
\hline & Rater & 163 & 1.20 & 1.01 & & Equal Variance not Assumed & $-3.73 *$ \\
\hline
\end{tabular}

* Statistically Significant. Differences at $p<0.05$

According to Table 7, transformational leadership and transactional leadership mean scores for raters are significantly lower than those of the leaders. The values of the standard deviation show that there is not much difference in variability of the scores of the two samples in the components of transactional leadership except in the aspect of contingent reward and Management-by-exception (Active), where there is a marginal difference. Striking marginal differences in standard deviation also exist in laissez-faire, all components of transformational leadership as well as transformational leadership as a whole.

The p-values indicate that there were significant differences between the responses of the leader and rater as their values were below the 0.05 significance value, except for Management-by-exception (Active), and Management-by-exception (Passive), which was above the 0.05 level of significance. This indicates that there is a major difference between leadership behaviours that are purported to be being practiced by managers and the behaviours that are being perceived by the employees except in the components of Management-by-exception (Active), and Management-by-exception (Passive).

\section{Results of the Correlation Analysis}

As mentioned previously, the hypotheses of the study were concerned with establishing a relationship between leadership style and employee commitment. The relationship between leadership style and organisational commitment was investigated using a two-tailed Pearson analysis. This provided correlation coefficients which indicated the strength and direction of linear relationship. The p-value indicated the probability of this relationship's significance. The results of the correlation analysis are presented below (Table 8). 
Table 8: Correlation Analysis

\begin{tabular}{|c|c|c|c|c|c|c|c|c|c|c|c|c|c|c|}
\hline & IA & IB & IC & IS & IM & TF & CR & MBEA & MBEP & TA & $\mathbf{L F}$ & $\mathbf{A C}$ & $\mathbf{C C}$ & $\mathbf{N C}$ \\
\hline IA & 1.000 & & & & & & & & & & & & & \\
\hline IB & $\begin{array}{l}0.818 \\
0.000 \\
\end{array}$ & 1.000 & & & & & & & & & & & & \\
\hline IC & $\begin{array}{l}0.837 \\
0.000\end{array}$ & $\begin{array}{l}0.775 \\
0.000\end{array}$ & 1.000 & & & & & & & & & & & \\
\hline IS & $\begin{array}{l}0.836 \\
0.000\end{array}$ & $\begin{array}{l}0.773 \\
0.000\end{array}$ & $\begin{array}{l}0.809 \\
0.000\end{array}$ & 1.000 & & & & & & & & & & \\
\hline IM & $\begin{array}{l}0.846 \\
0.000 \\
\end{array}$ & $\begin{array}{l}0.862 \\
0.000 \\
\end{array}$ & $\begin{array}{l}0.808 \\
0.000\end{array}$ & $\begin{array}{l}0.800 \\
0.000 \\
\end{array}$ & 1.000 & & & & & & & & & \\
\hline TF & $\begin{array}{l}0.941 \\
0.000\end{array}$ & $\begin{array}{l}0.915 \\
0.000\end{array}$ & $\begin{array}{l}0.917 \\
0.000\end{array}$ & $\begin{array}{l}0.913 \\
0.000\end{array}$ & $\begin{array}{l}0.937 \\
0.000\end{array}$ & 1.000 & & & & & & & & \\
\hline CR & $\begin{array}{l}0.849 \\
0.000 \\
\end{array}$ & $\begin{array}{l}0.853 \\
0.000 \\
\end{array}$ & $\begin{array}{l}0.860 \\
0.000 \\
\end{array}$ & $\begin{array}{l}0.851 \\
0.000 \\
\end{array}$ & $\begin{array}{l}0.851 \\
0.000 \\
\end{array}$ & $\begin{array}{l}0.923 \\
0.000 \\
\end{array}$ & 1.000 & & & & & & & \\
\hline MBEA & $\begin{array}{l}0.422 \\
0.000\end{array}$ & $\begin{array}{l}0.486 \\
0.000 \\
\end{array}$ & $\begin{array}{l}0.396 \\
0.000 \\
\end{array}$ & $\begin{array}{c}-0.330 \\
0.000\end{array}$ & $\begin{array}{l}0.374 \\
0.000\end{array}$ & $\begin{array}{l}0.453 \\
0.000 \\
\end{array}$ & $\begin{array}{l}0.370 \\
0.000 \\
\end{array}$ & 1.000 & & & & & & \\
\hline МВEP & -0.519 & $\begin{array}{c}-0.495 \\
0.000\end{array}$ & $\begin{array}{c}-0.477 \\
0.000\end{array}$ & $\begin{array}{c}-0.597 \\
0.000\end{array}$ & $\begin{array}{c}-0.501 \\
0.000\end{array}$ & $\begin{array}{c}-0.560 \\
0.000\end{array}$ & $\begin{array}{c}-0.529 \\
0.000\end{array}$ & $\begin{array}{c}-0.237 \\
0.002\end{array}$ & 1.000 & & & & & \\
\hline TA & $\begin{array}{l}0.576 \\
0.000 \\
\end{array}$ & $\begin{array}{l}0.644 \\
0.000 \\
\end{array}$ & $\begin{array}{l}0.602 \\
0.000 \\
\end{array}$ & $\begin{array}{l}0.528 \\
0.000 \\
\end{array}$ & $\begin{array}{l}0.571 \\
0.000 \\
\end{array}$ & $\begin{array}{l}0.638 \\
0.000 \\
\end{array}$ & $\begin{array}{l}0.652 \\
0.000 \\
\end{array}$ & $\begin{array}{l}0.766 \\
0.000 \\
\end{array}$ & $\begin{array}{l}0.065 \\
0.409 \\
\end{array}$ & 1.000 & & & & \\
\hline LF & $\begin{array}{r}-0.577 \\
0.000\end{array}$ & $\begin{array}{c}-0.489 \\
0.000\end{array}$ & $\begin{array}{c}-0.490 \\
0.000\end{array}$ & $\begin{array}{c}-0.557 \\
0.000\end{array}$ & $\begin{array}{c}-0.505 \\
0.000\end{array}$ & $\begin{array}{c}-0.555 \\
0.000\end{array}$ & $\begin{array}{c}-0.540 \\
0.000\end{array}$ & $\begin{array}{c}-0.139 \\
0.077\end{array}$ & $\begin{array}{l}0.711 \\
0.000\end{array}$ & $\begin{array}{c}-0.044 \\
0.579\end{array}$ & 1.000 & & & \\
\hline AC & $\begin{array}{l}0.211 \\
0.007\end{array}$ & $\begin{array}{l}0.198 \\
0.011\end{array}$ & $\begin{array}{l}0.191 \\
0.015\end{array}$ & $\begin{array}{l}0.112 \\
0.156\end{array}$ & $\begin{array}{c}0.21 \\
0.007\end{array}$ & $\begin{array}{l}0.209 \\
0.007\end{array}$ & $\begin{array}{l}0.216 \\
0.006\end{array}$ & $\begin{array}{c}-0.014 \\
0.864\end{array}$ & $\begin{array}{c}-0.113 \\
0.153\end{array}$ & $\begin{array}{l}0.106 \\
0.178\end{array}$ & $\begin{array}{c}-0.186 \\
0.018\end{array}$ & 1.000 & & \\
\hline $\mathrm{CC}$ & $\begin{array}{l}0.243 \\
0.002 \\
\end{array}$ & $\begin{array}{l}0.159 \\
0.043\end{array}$ & $\begin{array}{l}0.239 \\
0.002\end{array}$ & $\begin{array}{l}0.244 \\
0.002\end{array}$ & $\begin{array}{l}0.232 \\
0.003 \\
\end{array}$ & $\begin{array}{l}0.249 \\
0.001\end{array}$ & $\begin{array}{l}0.232 \\
0.003 \\
\end{array}$ & $\begin{array}{l}0.051 \\
0.383\end{array}$ & $\begin{array}{c}-0.126 \\
0.111\end{array}$ & $\begin{array}{l}0.146 \\
0.064\end{array}$ & $\begin{array}{c}-0.112 \\
0.153\end{array}$ & $\begin{array}{l}0.651 \\
0.000\end{array}$ & 1.000 & \\
\hline NC & $\begin{array}{l}0.280 \\
0.000\end{array}$ & $\begin{array}{l}0.257 \\
0.001\end{array}$ & $\begin{array}{l}0.248 \\
0.001\end{array}$ & $\begin{array}{l}0.232 \\
0.003\end{array}$ & $\begin{array}{l}0.298 \\
0.000\end{array}$ & $\begin{array}{l}0.292 \\
0.000\end{array}$ & $\begin{array}{l}0.291 \\
0.000\end{array}$ & $\begin{array}{l}0.081 \\
0.304 \\
\end{array}$ & $\begin{array}{c}-0.116 \\
0.142\end{array}$ & $\begin{array}{l}0.211 \\
0.007\end{array}$ & $\begin{array}{r}-0.197 \\
0.012\end{array}$ & $\begin{array}{l}0.763 \\
0.000\end{array}$ & $\begin{array}{l}0.646 \\
0.000\end{array}$ & 1.00 \\
\hline
\end{tabular}

The individual research hypotheses as documented earlier in this research were tested. The results of these hypotheses are given below.

Table 9: Summary of Hypotheses Results

\begin{tabular}{|c|c|c|c|c|}
\hline & & \\
\hline & & $\begin{array}{c}\text { Transformational } \\
\text { Leadership }\end{array}$ & $\begin{array}{c}\text { Transactional } \\
\text { Leadership }\end{array}$ & $\begin{array}{c}\text { Laissez-Faire } \\
\text { Leadership }\end{array}$ \\
\hline \multirow[t]{2}{*}{ Affective Commitment } & r-value & $0.209^{*}$ & 0.106 & $-0.186^{*}$ \\
\hline & & Accept & Reject & Accept \\
\hline \multirow[t]{2}{*}{ Normative Commitment } & r-value & $0.292 *$ & $0.211 *$ & $-0.197 *$ \\
\hline & & Accept & Accept & Accept \\
\hline \multirow[t]{2}{*}{ Continuance Commitment } & r-value & $0.249^{*}$ & 0.146 & -0.112 \\
\hline & & Accept & Reject & Reject \\
\hline
\end{tabular}

* signif. at $\mathrm{p} \leq 0.05$

From Table 9 it is clear that there is a relatively weak, but significant, positive relationship between transformational leadership and affective commitment $(\mathrm{r}=0.209, p<0.007)$. The study rejects the null hypothesis $\left(\mathrm{H}_{01}\right)$ and concludes that there is significant evidence, between transformational leadership and affective commitment since $\mathrm{p}<0.05$.

Further from Table 9, it is evident that there is a very weak, but significant, positive relationship between transformational leadership and continuance commitment $(\mathrm{r}=0.249, p<0.001)$. Hence, the study rejects the null hypothesis $\left(\mathrm{H}_{\mathbf{0 2}}\right)$ and concludes that there is sufficient evidence, at the $95 \%$ level of significance, that there is a positive relationship between transformational leadership and continuance commitment.

From Table 9, it is clear that there is a relatively weak, but significant, positive relationship between transformational leadership and normative commitment $(\mathrm{r}=0.292, p<0.000)$. The researcher rejects the null hypothesis $\left(\mathrm{H}_{\mathbf{0 3}}\right)$ and concludes that there is sufficient evidence, at the $95 \%$ level of significance, that there is a positive relationship between transformational leadership and normative commitment. 
There is an extremely weak, positive but insignificant relationship between transactional leadership and affective commitment $(\mathrm{r}=0.106, p<0.178)$. The researcher therefore accepts the null hypothesis $\left(\mathrm{H}_{04}\right)$ and concludes that there is insufficient evidence, at the $95 \%$ level of significance, of a significant relationship between transactional leadership and affective commitment.

There is a weak, positive relationship between transactional leadership and continuance commitment $(\mathrm{r}=$ $0.146, p<0.064)$. The researcher accepts the null hypothesis $\left(\mathrm{H}_{05}\right)$ and concludes that there is insufficient evidence, at the $95 \%$ level of significance, that there is a significant relationship between transactional leadership and continuance commitment.

There is a weak, but significant, positive relationship between transactional leadership and normative commitment $(\mathrm{r}=0.211, \mathrm{p}<0.007)$. The researcher therefore rejects the null hypothesis $\left(\mathrm{H}_{\mathbf{O 6}}\right)$ and concludes that there is sufficient evidence, at the $95 \%$ level of significance, of a significant relationship between transactional leadership and normative commitment.

There is a weak, but significant, negative relationship between laissez-faire leadership and affective commitment $(\mathrm{r}=-0.186, p<0.018)$. The researcher rejects the null hypothesis $\left(\mathrm{H}_{07}\right)$ and concludes that there is sufficient evidence, at the $95 \%$ level of significance, that there is a significant negative relationship between laissezfaire leadership and affective commitment.

There is a very weak, but insignificant, negative relationship between laissez-faire leadership and continuance commitment $(\mathrm{r}=-0.112, p<0.153)$. The researcher therefore cannot reject the null hypothesis $\left(\mathrm{H}_{08}\right)$ and concludes that there is insufficient evidence, at the $95 \%$ level of significance, of a significant relationship between laissez-faire leadership and continuance commitment.

There is a weak, but significant, negative relationship between laissez-faire leadership and normative commitment $(\mathrm{r}=-0.197, p=0.012)$. The researcher therefore rejects the null hypothesis $\left(\mathrm{H}_{09}\right)$ and concludes that there is sufficient evidence, at the $95 \%$ level of significance, of relationship between laissez-faire leadership and normative commitment.

Within the research design of this study, it was originally intended to perform a regression analysis to test for the hypothesis. However, this could not be conducted due to the correlation analysis results being weak, namely all correlation coefficients fall below 0.5, indicating a weak relationship between the leadership dimensions and organisational commitment within this study (Devore \& Peck, 1993). Therefore, the weak correlation results inhibited a regression analysis of the hypothesis.

\section{DISCUSSION}

This study found the average Cronbach's alpha reliability coefficient for the MLQ instrument to be 0.973, which, according to Nunnally and Bernstein (1994), are "desirable". Therefore, for the purposes of this research, the MLQ instrument was deemed to be a reliable measure of transformational leadership, transactional leadership and laissez-faire leadership.

This study found the average Cronbach's alpha reliability coefficient for the OCQ instrument to be 0.94 , which is good. The individual factors for the OCQ namely; Affective commitment, Normative Commitment and Continuance commitment had alpha scores of $0.91,0.90$ and 0.89 respectively. Therefore, for this research, the OCQ instrument was a reliable measure of affective commitment, continuance commitment and normative commitment.

The results of descriptive statistics indicated that whilst leadership in the said Parastatal is more transformational than transactional, the average combined scores for the individual factors were well below the ideal scores. It was also noted that the average combined scores of the individual factors were below the average South African scores. This means that managers are not displaying the ideal levels of transformational leadership behaviours. These behaviours included engendering trust, inspiring a shared vision, generating enthusiasm, encouraging creativity and providing coaching. It also seems that some employees perceived their immediate 
managers as doing an above average job of clarifying expectations and recognising accomplishments and taking corrective action in a timely manner, whilst some managers tended to wait too long before resolving a problem or taking corrective action.

The correlation results suggest that although the relationship is not strong, there is a positive relationship between the transformational leadership behaviours and commitment (affective commitment $(r=0.209$ ), continuance commitment $(r=0.249)$ and normative commitment $(r=0.292)$ ). This suggests that leadership behaviours, which involve building trust, inspiring a shared vision, encouraging creativity and emphasising development, is somewhat positively related to employee commitment.

Affective commitment is the employee's emotional attachment to, identification with, and involvement in the organisation (Meyer \& Allen, 1997), and refers to an individual's attitude towards the organisation, consisting of a strong belief in, and acceptance of, an organisation's goals, willingness to exert considerable effort on behalf of the organisation and a strong desire to maintain membership in the organisation. This is critical to the organisation, as affective commitment results in better performance and more meaningful contributions than normative commitment and continuance commitment (Meyer \& Allen, 1997). According to Meyer and Allen (1997), employees who stay with an organisation because they feel obligated or need to, do not exhibit the same enthusiasm and involvement as employees who stay with the organisation because they want to stay. Our results indicate that employees lean more towards Normative and Continuance commitment. Continuance commitment is the extent to which employees perceive that they have to stay with the organisation, because the costs of leaving are too high. Employees with a strong continuance commitment remain with the organisation because it provides them with desirable personal outcomes and benefits that they are unwilling to sacrifice. Employees with high continuance commitment engage in certain behaviours, not because they feel that it is the right thing to do or because they want to do it, but because they believe that they will derive some reward(s) or minimise some cost(s) from doing so.

Employees also feel that they are morally obliged to remain with the organisation (Meyer et al., 1993) despite better work opportunities elsewhere in the labour market. A sense of loyalty and duty underlying an employee's normative commitment influences employees' decision to remain with the employing organisation because they feel they ought to do so (Bagraim, 2003; Meyer et al., 1993). Employees with normative commitment believe people ought to be loyal to their employer and are obliged to remain with them (Cohen \& Kirenmey, 1995). The feelings of obligation and loyalty stop an employee with normative commitment from leaving an organisation. Whatever happens to an organisation be it positive or negative will affect employees with normative behaviour. Allen and Meyer (1990), for example, found that an employee would have strong normative commitment to the organisation if significant others (such as relatives) have been long-term employees of the organisation and have stressed the importance of organisational loyalty.

Other researchers have also found weak positive relationships between transformational leadership behaviours and affective commitment, normative commitment, as well as, continuance commitment. Lo, Ramayah, Min and Songan (2010) found a positive direct relationship between three dimensions of transformational leadership styles, namely intellectual stimulation, idealised influence and inspirational motivation, and affective and normative commitment. They also found that two dimensions of transformational leadership, namely intellectual stimulation and individualised consideration, were found to have a positive relationship with continuance commitment.

In a study undertaken by Kent and Chelladurai (2001) in inter-collegiate athletics at an American University, it was found that individualised consideration has a positive correlation with both affective commitment $(\mathrm{r}=0.475, \mathrm{p}<0.001)$ and normative commitment $(\mathrm{r}=0.354, \mathrm{p}<0.001)$. They also found positive correlations between intellectual stimulation and both affective commitment $(r=0.487, \mathrm{p}<0.001)$ and normative commitment $(\mathrm{r}$ $=0.292, \mathrm{p}<0.05)$. Bycio, Hackett and Allen (1995) found a weak correlation between the transformational leadership dimensions and affective commitment. They found correlations of between $r=0.39$ and $r=0.45$. Also, Podsakoff and his colleagues (1996) reported weak correlation ranges from $r=0.25$ to $r=0.34$ between commitment and different dimensions of transformational leadership. In another study undertaken by Hayward, Goss and Tolmay (2004) in the South African electricity utility of Eskom Southern Region, it was found that transformational leadership had a moderate positive correlation with affective commitment $(r=0.5278, p<0.000)$. They also found that there was no significant linear relationship between transactional leadership and any of the 
commitment types. Nyengane (2007) obtained similar results in a study done at Eskom's Eastern Region. He found that transformational leadership had a weak positive correlation with commitment ranging from $r=0.453$ for affective commitment to $\mathrm{r}=0.175$ for continuance commitment.

In this study the weak, but significant, positive correlation between transactional leadership and normative commitment suggests that leadership behaviours involving clarification of goals, exchange of rewards for meeting agreed-on objectives, highlighting problems, specifying the standards for compliance, as well as what constitutes ineffective performance, and punishing followers for being out of compliance with those standards, as well as closely monitoring for deviances, mistakes, and errors and then taking corrective action as quickly as possible when they occur, seem to inspire a sense of loyalty and duty, thus encouraging the degree of normative commitment. There was no statistically significant correlation between transactional leadership behaviours and affective commitment as well as between transactional leadership behaviours and continuance commitment. This is in contrast to Nyengane (2007) who found a weak, but significant, positive relationship between transactional leadership and continuance commitment.

A weak, but significant and negative correlation between laissez-faire leadership behaviour and affective commitment as well as normative commitment, suggest that leaders who avoid getting involved when important issues arise, are absent when needed, avoid making decisions and who delay responding to urgent questions, negatively affect an employee's emotional attachment to the organisation, as well as their decision to remain with the organisation. Nyengane (2007) indicated a weak, but significant and negative correlation between laissez-faire leadership behaviour and affective commitment.

Because transformational leadership has been found to have a significant positive relationship with employee commitment, the organisation should attempt to develop this leadership style, as committed employees are most desirable. By implementing programmes that encourage leaders to develop transformational leadership style, the organisation will be able to improve the commitment levels of its employees.

One of the reasons why there is a weak correlation between transformational leadership behaviour and organisational commitment could be the fact that professionals derive their rewards from inward standards of excellence, from their professional societies and from the intrinsic satisfaction of their task (Toffler, 1990). Toffler (1990) argues that professionals are committed to the task, not the job; to their standards, not their boss. And because they have degrees or diplomas, they easily move from one company to another. They are not good 'company men'; they are committed to the challenging environments where they can play with problems. This reasoning might also explain the lower scores for affective and continuance commitment.

Haug and Dofny (1997) indicated that professionals' goals are directed primarily inward, at achieving the goals of the company and advancing within the company. The principal motivator for a professional is to have an interesting job and a feeling of personal and professional growth. They may be able to handle many shortcomings in the work situation, if the work itself is challenging. Raudsepp (1977) argues that the professionals' attitude towards their job is self-directing and they are normally quite happy when given limited supervision. They know they are part of a team, but they still prefer the company to have confidence in their capabilities so that they can earn greater independence. Dunham, Grube and Castaneda (1994) suggest that this relationship could vary based on employees' perceptions of their ability to find another job with similar characteristics. Furthermore, it is the fear of loss that commits the person to the organisation (Meyer \& Allen, 1984).

In general, it may be concluded that respondents who are affectively committed to the organisation are more willing to maintain their relationship with the organisation than those who are normatively and continuance committed. Affectively committed employees will thus portray feelings of identification with the organisation, and attachment to and involvement in the organisation. This is in contrast with the other two dimensions of commitment, which focus on commitment by virtue of the cost associated with leaving and a feeling of obligation to remain with the organisation.

The results of the study have important implications for the company that participated in the study as well as for other South African organisations, which can learn from these results. An important deduction from the results 
is that by focusing on affective and normative commitment, organisations will be able to positively influence the retention of employees, productive behaviour and employee well-being. The opposite focus, namely emphasising continuance commitment, or the cost of leaving, will not ensure the same positive results.

\section{LIMITATIONS}

The findings of this study should be viewed with certain limitations in mind. The limitation of the current study relates to the characteristics or demographics of the sample as well as that age was not collected as a control variable. Previous research (Hrebiniak \& Alutto, 1972; Steers, 1977) has suggested that age can affect organisational commitment. Given that age was not collected as a control variable, the impact of this omission is unknown. The study was dominated by mostly male participants, thus, results might have been different if percentages for race, age, marital status, gender, time with the organisation, time with an immediate supervisor, ethnicity and education were different.

A third limitation of the empirical study is related to the sample or population group. All the respondents were from a single organisation, which could influence their perceptions due to its practices and other factors. The results can thus not be generalised to organisations in any sectors. Generalisation of the present findings should therefore be examined in future research in other regions, with mixed gender, older and more heterogeneous samples.

\section{CONCLUSIONS}

The main objective of the study was to investigate the relationship between various leadership styles and various employee commitment styles at the selected Parastatal company in South Africa. This study found that the transformational leadership behaviours were positively related with affective, continuance and normative commitment, although not very strongly. This means that leadership behaviours which involve engendering trust, inspiring a shared vision, generating enthusiasm, encouraging creativity, providing coaching and recognising accomplishments, had some impact on how employees feel about wanting to, needing to, or feeling obligated to, stay with the organisation. The more they display these behaviours, the more employees may want to, need to, or feel obligated to stay.

Transactional leadership behaviours had a positive relationship with normative commitment. This indicates that leadership behaviours, which involve the clarification of goals and objectives and providing of recognition once goals are achieved, specifying the standards for compliance, as well as what constitutes ineffective performance, and punishing followers for being out of compliance with those standards as well as closely monitoring for deviances, mistakes, and errors and then taking corrective action as quickly as possible seem to encourage how employees feel about needing to stay with the organisation.

These findings also reveal that the laissez-faire leadership behaviour has a negative relationship with affective, normative and continuance commitment. This emphasises that leadership behaviours, which involve avoiding getting involved when problems arise, will negatively impact on affective commitment. This also explains some of the variation in how employees feel about not wanting to stay with the organisation.

The existing leadership and management research suggest that the leadership style of managers can lead to higher measures of organisational commitment in their direct reports. This study has demonstrated positive relationships between leadership styles and organisational commitment. Overall findings from this study suggest that transformational, transactional and laissez-faire leadership behaviours do play important roles in determining levels of affective commitment, continuance commitment and normative commitment.

\section{ACKNOWLEDGEMENT}

The authors express their gratitude to the anonymous referees for their comments for improving the quality of this paper. We acknowledge the literary support provided by Mrs. Eunice Mtshali and her team from the library. Special thanks to the TUT Business School for bearing the publication costs and Mrs. Riana Knighton for her administrative support. 


\section{AUTHOR INFORMATION}

Prof. Ajay K Garg, 159 Nana Sita Road, TUT Business School, Pretoria, South Africa. E-mail: Gargak@tut.ac.za; akg20055@yahoo.co.in (Corresponding author)

Mr. D. Ramjee, P.O.Box 13425, Laudium, Pretoria, South Africa 0037.

\section{REFERENCES}

1. Ackermann, C.P., Schepers, J.M., Lessing, B.C. \& Dannhauser, Z. 2000. Die Faktorstruktuur van Bass se Veelfaktor Leierskapsvraelys in die Suid-Afrikaanse Konteks. Journal of Industrial Psychology, 26(2): 5865.

2. Allen, N.J. \& Meyer, J.P. 1990. The measurement and variables associated with affective, continuance and normative commitment to the organization. Journal of Occupational Psychology, 63: 1-18.

3. Allen, N. J. \& Meyer, J. P. 1996. Affective, continuance, and normative commitment to the organization: An examination of construct validity. Journal of Vocational Behaviour, 49: 252.

4. Alqudah, T.G. 2011. Leadership style and organizational commitment. MBA dissertation, Kuala Lumpur: Open University Malaysia.

5. Angle, H.L. \& Perry, J. 1981. An empirical assessment of organizational commitment and organization effectiveness. Administrative Science Quarterly, 26: 1-14.

6. Antonakis, J., Avolio, B.J. \& Sivasubramaniam, N. 2003. Context and leadership: An examination of the nine factor full-range leadership theory using the multifactor leadership questionnaire. The Leadership Quarterly, 14(3): 261-295.

7. Avolio, B.J. 1999. Full leadership development: Building the vital forces in organizations. Thousand Oakes, CA: Sage.

8. Avolio, B.J. \& Bass, B.M. 1991. The full-range of leadership development: Basic and advanced manuals. Binghamton, NY: Bass, Avolio \& Associates.

9. Avolio, B.J. \& Yammarino, F.J. 2003. Transformational and charismatic leadership: The road ahead. Oxford: Elsevier.

10. Avolio, B.J., Zhu, W.C., Koh, W. \& Bhatia, P. 2004. Transformational leadership and organizational commitment: mediating role of psychological empowerment and moderating role of structural distance. Journal of Organizational Behaviour. 25: 951-68.

11. Bagraim, J.J. 2002. Organizational commitment amongst South African knowledge workers: Some preliminary findings. Cape Town: University of Cape Town.

12. Bagraim, J.J. 2003. The nature of measurement of multiple commitment foci amongst South African knowledge workers. Management Dynamics, 12(2): 13-23.

13. Bagraim, J.J. 2010. Multiple affective commitments and salient outcomes: The Improbable Case of information technology knowledge workers. The Electronic Journal Information Systems Evaluation, 13(2): 97-106.

14. Baloch, Q.B., Ali, N. \& Zaman, G. 2010. Measuring employees' commitment as outcome of transformational and transactional leadership styles: an empirical study. Abasyn Journal of Social Sciences, 3(2): 210-216.

15. Bass, B.M. 1985a. Leadership: good, better, best. Organizational Dynamics, 3(3): 26-40.

16. Bass, B.M. 1985b. Leadership and performance beyond expectations. New York, NY: Free Press.

17. Bass, B.M. 1990a. Bass and Stogdill's handbook of leadership: Theory, research and managerial applications. New York, NY: Free Press.

18. BASS, B.M. 1994. Improving Organizational effectiveness through Transformational Leadership. Thousand Oaks, CA: Sage.

19. Bass, B.M. 1997. Does the transactional-transformational leadership paradigm transcend organizational and national boundaries? Journal of American Psychologist, 52(2): 130-139.

20. Bass, B.M. 1998. Transformational leadership: Military and civilian impact. Mahwah, NJ: Lawrence Erlbaum.

21. Bass, B.M. 1999. Two decades of research and development in transformational leadership. European Journal of Work and Organizational Psychology, 8(1): 9-32. 
22. Bass, B.M. \& AVOLIO, B.J. 1990c. Training and development of transformational leadership for individual, team, and organizational development. In: Woodman, R.W. \& Passmore, W.A. (Eds.). Research in organizational change and development. Greenwich, CT: JAI Press.

23. Bass, B.M. \& Avolio, B.J. 1991. Assessing leadership across the full-range. (Paper read at the Society for Industrial and Organizational Psychology, Miami, FL. Unpublished.

24. Bass, B.M. \& Avolio, B.J. 1993. Transformational leadership: A response to critiques. In: Leadership theory and research, perspective, and directions. San Diego: Academic Press: 49-80.

25. Bass, B.M. \& Avolio, B.J. 1994. Improving Organizational Effectiveness through Transformational Leadership. Thousand Oakes, CA: Sage.

26. Bass, B.M. \& Avolio, B.J. 1997. Full range of leadership development: Manual for the Multi-factor Leadership Questionnaire. Thousand Oakes, CA: Mind Garden.

27. Bass, B.M. \& Avolio, B.J. 2000. Multifactor leadership questionnaire: Sampler set. $2^{\text {nd }}$ ed. Redwood City, CA: Mind Garden.

28. Bass, B.M., Avolio, B.J., Jung, D.I. \& Berson, Y. 2003. Predicting unit performance by assessing transformational and transactional leadership. Journal of Applied Psychology, 88: 207-218.

29. Bateman, T. \& Strasser, S. 1984. A Longitudinal Analysis of the Antecedents of Organizational Commitment. Academy of Management Journal, 27: 95-112.

30. Bennis, W.G. \& NannuS, B. 1985. Leaders: The strategies for taking charge. New York, NY: Harper and Row.

31. Bono, J. \& Judge, T. 2003. Self-concordance at work: toward understanding the motivational effects of transformational leadership. Academy of Management Journal, 46: 554-571.

32. Bryman, A. 2011. The SAGE Handbook of Leadership. London: Sage.

33. Buhler, P. 1995. Leaders versus. Managers. Supervision, 56(5): 4.

34. Bull, I.H.F. 2005. The Relationship between Job Satisfaction and Organisational Commitment amongst high school teachers in disadvantaged areas in the Western Cape. M.Sc. (Psyc) dissertation, Cape Town, University of the Western Cape.

35. Burns, J.M. 1978. Leadership. New York, NY: Harper and Row.

36. Bycio, P., Hackett, R. \& Allen, J. 1995. Further assessment's of Bass's (1985) conceptualization of transactional and transformational leadership. Journal of Applied Psychology, 80: 468-478.

37. Carnegie, D. 1995. Performance of North Sea offshore platform supervisors. PhD thesis, Aberdeen: Aberdeen University.

38. Catanyag, D.V. 1995. Effects of transformational leadership behaviours of public secondary school principals in the national capital region on school effectiveness. Doctoral dissertation, Manila, University of the Philippines.

39. Clayton, B.M. \& Hutchinson, M.R. 2001. Organisational commitment of accountants in Australia and South Africa. South African Journal of Accounting Research, 16(01): 1-17.

40. Cohen, A. \& Kirenmey, C.L. 1995. A Multidimensional approach to the relationship between organisational commitment and non-work participation. Journal of Vocational Behaviour, 49: 189-2002.

41. Davenport, J. 2010. Leadership style and employee commitment: The moderating effect of locus of control. Conference held in Las Vegas in February 2010. ASBBS, 17(1): 277-290.

42. Davis, D.D., Guaw, P., Luo, J. \& Maahs, C.J. 1997. Need for continuous improvement, organization citizenship, transformational leadership, and service climate in a Chinese state enterprise. (Paper read at the conference on Society for Organizational and Industrial Psychology, August, St. Louis, MO). Unpublished.

43. Den Hartog, D.N. 1997. Inspirational leadership. Academisch Profschrift. Amsterdam: Free University of Amsterdam.

44. Devore, J. \& Peck, R. 1993. Statistics - the exploration and analysis of data. California: Wadsworth.

45. Dubinsky, A.J., Yammarino, F.J., Jolson, M.A. \& William D.S. 1995. Transformational Leadership: An Initial Investigation in Sales Management. Journal of Personal Selling and Sales Management, 15(2): 1731.

46. Dumdum, U.R., Lowe, K.B. \& Avolio, B.J. 2002. A Meta-analysis of the transformational and transactional leadership correlates of effectiveness and satisfaction: An update and extension. In: Avolio, B.J. (ed.). Transformational and Charismatic Leadership. Amsterdam: JAI Press: 35-66.

47. Dunham, R., Grube, J. \& Castaneda, M. 1994. Organisational commitment: The utility of an interaction definition. Journal of Applied Psychology, 79: 370-380. 
48. Fuller, J.B., Patterson, C., Hester, K. \& Stringer, D.Y. 1996. A quantitative review of research on charismatic leadership. Psychological Reports, 78: 271-287.

49. Gaspar, S. 1992. Transformational leadership: An integrative review of the literature. PhD. thesis, Kalamazoo, MI, Western Michigan University.

50. GbadamOSI, G. 2003. HRM and the commitment rhetoric: Challenges for Africa, Management Decision, 41(3): 274-280.

51. Geyer, A.L. \& Steyrer, J. 1998. Transformational leadership, classical leadership dimensions and performance indicators in savings banks. Leadership Quarterly, 47: 397-420.

52. Guang-Lu, D., Pu, L. \& Yong, Z. 2012. Organizational justice as a moderator of relationship between the transformational leadership and organizational commitment. International Journal of Humanities and Social Science, 2(15): 116-122.

53. Haug, M.R., \& Dofny, J. 1997. Work and Technology, Sage studies in international sociology. London: Sage.

54. Hayward, B.A. 2005. Relationship between employee performance, leadership and emotional intelligence in a South African parastatal organisation. M.Com. dissertation, Grahamstown. Rhodes University.

55. Hayward, Q., Goss, M. \& Tolmay, R. 2004. The Relationship between Transformational and Transactional leadership and employee commitment. Grahamstown, Rhodes University: Business Report.

56. Howell, J.M., \& Avolio, B.J. 1993. Transformational leadership, transactional leadership, locus of control, and support for innovation: Key predictors of consolidated business business-unit performance. Journal of Applied Psychology, 78: 891-902.

57. Hrebiniak, L. \& Alutto, J. 1972. Personal and role-related factors in the development of organizational commitment. Administrative Science Quarterly, 17: 555-572.

58. Jung, D. I. 2001. Transformational and transactional leadership and their effects on creativity in groups. Creativity Research Journal, 13(2): 185- 195.

59. Kent, A. \& Chelladurai, P. 2001. Perceived transformational leadership, organizational commitment, and citizenship behaviour: a case study in intercollegiate athletics. Journal of sport management, 15(2): 135159.

60. KINNEAR, S. 2000. Determinants of organisational commitment among knowledge workers. South African Journal of Business Management, 31(3):106-112.

61. Koh, W.L., Steers, R.M., \& Terborg, J.R. 1995. The effects of transformational leadership on teacher attitudes and student performance in Singapore. Journal of Organizational Behaviour, 16: 319-333.

62. Koh, W.L., Terborg, J.R. \& Steers, R.M. 1991. The impact of transformational leadership on organizational commitment, organizational citizenship behaviour, teacher satisfaction and student performance in Singapore. (Paper read at the $51^{\text {st }}$ Annual Meeting of the Academy of Management, August 9-12, Miami Beach, FL.). Unpublished.

63. Lee, J. 2005. Effects of leadership and leader-member exchange on commitment. Leadership \& Organization Development Journal, 26(7/8): 655-673.

64. Lo, M., Ramayah, T. \& Min, H.W. 2009. Leadership styles and organizational commitment: a test on Malaysia manufacturing industry. African Journal of Marketing Management, 1(6): 133-139.

65. Lo, M. C., Ramayah, T., Min, H.W. \& Songan, P. 2010. The Relationship between Leadership Styles and Organizational Commitment in Malaysia: Role of Leader-Member Exchange. Asia Pacific Business Review, 16(1): 79-102.

66. Lowe, K.B., Kroeck, K.G., \& Sivasubramaniam, N. 1996. Effectiveness correlates of transformational and transactional leadership: a meta-analytical review of the literature. Leadership Quarterly, 7: 385-425.

67. Lumley, E.J., Coetzee, M., Tladintane, R. \& Ferreira, N. 2011. Exploring the job satisfaction and organisational commitment of employees in the information technology environment. Southern African Business Review, 15(1): 100-118.

68. Manetje, O. \& Martins, N. 2009. The relationship between organisational culture and organisational commitment. Southern African Business Review, 13(1): 87-111.

69. Maritz, D. 1995. Leadership and mobilising potential. Human Resource Management, 10(1): 8-16.

70. Marmaya, N.H., Hitam, M., Muhamad Torsiman, N. \& Balakrishnan, B. 2011. Employees' perception of Malaysian managers' leadership styles and organizational commitment. African Journal of Business Management, 5(5): 1584-1588.

71. Marturano, A. \& Gosling, J. 2007. Leadership: The key concepts. New York, NY: Routledge. 
72. Meyer, J.P. \& Allen, N.J. 1984. Testing the "side-bet theory" of organizational commitment: some methodological considerations. Journal of Applied Psychology, 69: 372-378.

73. Meyer, J.P. \& Allen, N.J. 1991. A three-component conceptualisation of organizational commitment. Human Resource Management Review, 1(1): 61-89.

74. Meyer, J.P. \& Allen, N.J. 1997. Commitment in the workplace. Thousand Oaks, CA: Sage.

75. Meyer, J.P., Allen, N.J. \& Smith, A. 1993. Commitment to organizations and occupations: Extension and test of a three-component conceptualization. Journal of Applied Psychology, 78: 538-555.

76. Meyer, J.P., Stanley, D.J., Hescovitch, L. \& Topolnytsky, L. 2002. Affective Continuance and Normative Commitment to the Organization. A meta- analysis of antecedents, correlates and consequences. Journal of Vocational Behaviour, 61(1): 20-52.

77. Molero, R. \& Morales, J.F. 1994. A study on leadership in a healthcare organization using Bass' Multifactor Leadership Questionnaire (MLQ). (Paper read at the $23^{\text {rd }}$ International Congress of Applied Psychology, July 17-22, Madrid, Spain). Unpublished.

78. Morrow, P. 1983. Concept redundancy in organizational research: The case of work commitment. Academy of Management Review, 8: 486-500.

79. Mowday, R.T., Porter, L.W. \& Dubin, R. 1974. Unit Performance, Situational Factors and Employee Attitudes in Spatially Separate Work Units. Organizational Behaviours and Human Performance, 12: 231248.

80. Muterera, J. 2008. The relationship between leadership theory behaviors, follower attitudes and behaviors and organizational performance in United States County Governments. PhD. thesis. Michigan, Western Michigan University.

81. Nunnally, J.C. \& Bernstein, I.H. 1994. Psychometric Theory. $3^{\text {rd }}$ ed. New York, NY: McGraw-Hill.

82. Nyengane, M.H. 2007. The relationship between leadership style and employment commitment: An explorative study in an electricity utility in South Africa. MBA thesis, Grahamstown, Rhodes University.

83. Podsakoff, P.M., Mackenzie, S.B. \& Bommer, W.H.R. 1996. Transformational leadership behaviours as determinants of employee satisfaction, commitment, trust, and organizational citizenship behaviours. Journal of Management, 22: 259-298.

84. Porter, L.W., Steers, R.M., Mowday, R.T., \& Boulian, P.V. 1974. Organizational Commitment, Job Satisfaction and Turnover among Psychiatric Technicians. Journal of Applied Psychology, 59(5): 603-609.

85. Price, J.L. 1997. Handbook of organizational measurement. International Journal of Manpower, 18(4/5/6): 305-558.

86. Pruijn, G.H.J. \& Boucher, R.J. 1994. The relationship of Transactional and Transformational Leadership to the Organisational Effectiveness of Dutch National Sports Organisations. European Journal of Sport Management, 2: 72-87.

87. Raudsepp, E. 1977. Motivating the Engineer: The direct approach is best. Machine Design, 11: 59-61.

88. Sabir, M.S., Sohail, A. \& Khan, A. 2011. Impact of leadership style on organisational commitment: In a mediating role of employee values. Journal of Economics and Behavioural Studies, 3(2): 145-152.

89. Schilbach, C. 1983. Die ontwikkeling van leierskapvaardighede by middelvlak- bestuurders. D.Phil thesis, Pretoria, University of Pretoria.

90. Shokane, M.S., Stanz, K.J. \& Slabbert, J.A. 2004. Description of Leadership in South Africa: Organisational context perspective. SA Journal of Human Resource Management. 2(3): 1-6.

91. Sosik, J.J. \& Jung, D. 2012. Full Range Leadership Development. New York, NY: Taylor and Francis.

92. Stogdill, R.M. 1974. Handbook of Leadership. New York, NY: Free Press.

93. Stum, D.L. 1999. Maslow revisited: Building the employee commitment pyramid. Strategy and Leadership, 29(4): 4-9.

94. Suliman, A.M. \& Isles, P.A. 2000a. Is continuance commitment beneficial to organizations? Commitmentperformance relationship: A new look. Journal of Managerial Psychology, 15(5): 407-426.

95. Toffler, A. 1990. Power Shift. New York, NY: Bantam Books.

96. Tonelli, B. 2008. Leadership Styles and Funding: An analysis of California Juvenile Delinquency Prevention Programs Receiving Federal Grants. Ann Arbor, MI: ProQuest.

97. Visagie, M.C. 2010. The relationship between employee attitudes towards planned organisational change and organisational commitment: an investigation of a selected case within the South African telecommunications industry. M.Tech. dissertation, Cape Town, Cape Peninsula University of Technology. 
98. Walumbwa, F.O. \& Lawler, J.J. 2003. Building effective organizations: transformational leadership, collectivist orientation, work-related attitudes, and withdrawal behaviors in three emerging economies. International journal of human resource management, 14: 1083-1101.

99. Yukl, G.A. 2009. Leadership in Organizations. New York, NY: Prentice-Hall. 
NOTES 